University of Louisville

ThinkIR: The University of Louisville's Institutional Repository

Electronic Theses and Dissertations

$5-2017$

\title{
Treg regulation in periodontal disease during pregnancy.
}

Aislinn Leah Hays

University of Louisville

Follow this and additional works at: https://ir.library.louisville.edu/etd

Part of the Oral Biology and Oral Pathology Commons

\section{Recommended Citation}

Hays, Aislinn Leah, "Treg regulation in periodontal disease during pregnancy." (2017). Electronic Theses and Dissertations. Paper 2685.

https://doi.org/10.18297/etd/2685

This Master's Thesis is brought to you for free and open access by ThinkIR: The University of Louisville's Institutional Repository. It has been accepted for inclusion in Electronic Theses and Dissertations by an authorized administrator of ThinkIR: The University of Louisville's Institutional Repository. This title appears here courtesy of the author, who has retained all other copyrights. For more information, please contact thinkir@louisville.edu. 
TREG REGULATION IN PERIODONTAL DISEASE DURING PREGNANCY

By

Aislinn Leah Hays

B.S., University of Washington, 2011

\begin{abstract}
A Thesis
Submitted to the Faculty of the

School of Dentistry of the University of Louisville

in Partial Fulfillment of the Requirements for the Degree of
\end{abstract}

Master of Science in Oral Biology

Department of Oral Immunology and Infectious Diseases

University of Louisville School of Dentistry

Louisville, KY

May 2017 
Copyright 2017 by Aislinn Hays

All rights reserved 

TREG REGULATION IN PERIODONTAL DISEASE DURING PREGNANCY

By

Aislinn Leah Hays

B.S., University of Washington, 2011

A Thesis Approved on

April 20, 2017

By the following Thesis or Dissertation Committee:

\begin{tabular}{c}
\hline Dr. Shuang Liang \\
\hline Dr. Donald Demuth \\
\hline
\end{tabular}

Dr. Huizhi Wang 


\section{DEDICATION}

This thesis is dedicated to my parents, Steve and Maria Hays; for endlessly supporting me in all my endeavors. 


\section{ACKNOWLEDMENTS}

First and foremost I would like to thank my mentor Dr. Shuang Liang for his guidance and support these past two years. I would also like to thank my committee members Dr. Donald Demuth and Dr. Huizhi Wang for dedicating their time and constructive input on developing this project. Additionally, I would like to thank Dr. Xingyu Duan, Dr. Wei Zhou, Dr. Satya Upadhyayula, Dr. Li Su for working with me as a team and spending the long hours helping me harvest and process all the tissue. Without all your help this project would not have succeeded. 


\title{
ABSTRACT \\ TREG REGULATION IN PERIODONTAL DISEASE DURING PREGNANCY
}

\author{
Aislinn L. Hays
}

April 20, 2017

Background: Although pregnancy is prone to induce more severe periodontal inflammation and tissue damage, its mechanism remains elusive. Periodontal diseases during pregnancy are associated with adverse pregnancy outcomes including preterm birth or low birth weight. Animal models are ideal for investigating immunological mechanisms in periodontal disease. With a newly modified ligature-induced disease model, we managed to develop periodontal disease in pregnant mice and investigate the immunological mechanism of more severe symptoms during pregnancy.

Hypothesis: We hypothesis that $P$. gingivalis infection during pregnancy will lead to a down-regulation of Treg cells, therefore causing increased inflammation and disease severity.

Methods: A ligature-induced murine model for periodontitis has been modified and utilized for periodontal inflammation and tissue damage determination in pregnant mice. Differential expression of inflammatory mediators in mouse gingivae was determined by quantitative real-time PCR. Inflammatory alveolar 
bone loss was determined by measuring the distance from the cementoenamel junction to the alveolar bone crest (CEJ-ABC). Oral bacteria number was determined by the CFU (Colony Forming Units) count from anaerobic culture of oral swabs. Draining lymph nodes were harvested and analyzed for Treg cells by flow cytometry.

Results: In comparison with non-pregnant mice, ligated and $P$. gingivalis infected pregnant mice displayed significantly $(p<0.05)$ increased gingival inflammation and periodontal bone loss, accompanied by decreased Treg cells and downregulated expression of Treg-related molecules and anti-inflammatory cytokines.

Conclusion: Our study has established a model to manifest that $P$. gingivalis infection causes aggravated periodontal disease during pregnancy, possibly through down-regulating Treg numbers and anti-inflammatory capability. 


\section{TABLE OF CONTENTS}

DEDICATION

iii

ACKNOWLEDMENTS

iv

ABSTRACT v

LIST OF FIGURES ix

CHAPTER 1: INTRODUCTION 1

Periodontal Disease. 1

CD4+ T Cells 3

Regulatory T cells in Periodontal Disease 6

Periodontal Disease during Pregnancy..... 7

CHAPTER 2: METHODS AND MATERIALS 11

Pregnancy Periodontal Disease Model 11

RNA Isolation and Quantification Reverse Transcription-PCR 12

Lymphocyte Isolation and Quantification by Flow Cytometry 13

Oral Bacteria Quantification .14 
Alveolar Bone Loss Quantification

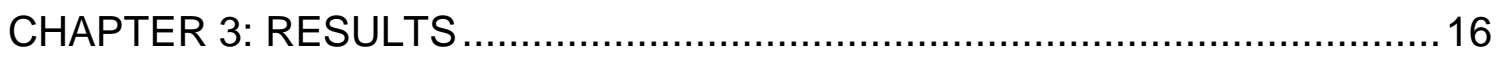

Ligation with $P$. gingivalis Infection Induced Higher Pro-inflammatory

Cytokine Expression in Pregnant Mice ............................................16

Greater Alveolar Bone Loss in P. gingivalis Infected Mice.....................19

Decreased Expression of Treg Related Molecules in Infection-induced

Pregnant Mice

Lower Percentage of Treg Cells in CD4+ T Cell Population in Draining Lymph Nodes of Infection-Induced Pregnant Mice

Increased Percentage of Th17 Cells in Pregnant Mice ..........................25

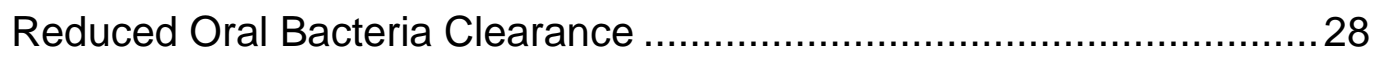

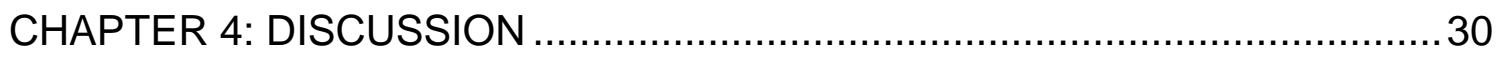

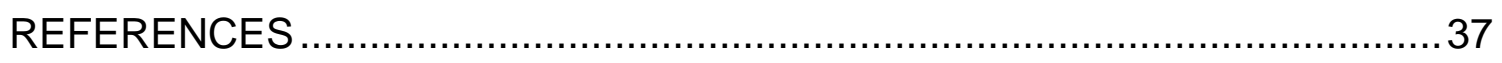

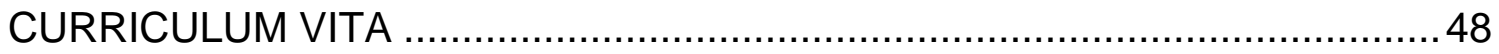




\section{LIST OF FIGURES}

FIGURE

PAGE

1. Schematic depiction of CD4+ T cell differentiation .5

2. Schematic depiction of ligation induced periodontal disease during pregnancy

3. Eosin methylene blue staining on maxillary jaw bone with depiction of 7 CEJ-ABC measurement sites

4. Higher expression of pro-inflammatory cytokines in the gingivae of ligated pregnant compared to non-pregnant mice with $P$. gingivalis infection

5. Ligation with $P g$ infection causes more severe bone loss in pregnant mice than non-pregnant mice

6. Decreased expression of Treg-related cytokines and molecules in the gingivae of ligated pregnant mice compared to non-pregnant mice with $P$. gingivalis infection

7. Increased percentage of Treg cells in ligated and Pg infected pregnant mice than non-pregnant mice

8. Decreased percentage of Th17 cells in ligated and $P g$ infected pregnant mice than non-pregnant mice

9. Infection-induced pregnant mice have greater number of oral bacteria compared to non-pregnant mice 
10. Schematic depiction of immunological mechanism of pregnancy inhibition

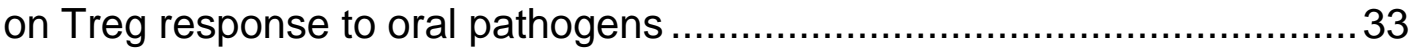




\section{CHAPTER 1: INTRODUCTION}

\subsection{PERIODONTAL DISEASE}

The human oral cavity is inhabited by approximately 700 species of prokaryotes; commonly referred to as the oral microbiome (T. Chen et al., 2010). Humans can maintain a healthy stable oral microbiome in which host-microbial interactions are in balance. However, shifts in microbiome composition leading to a dysbiotic state can initiate the development of oral diseases (Mira, Simon-Soro, \& Curtis, 2017). The oral cavity provides various habitats in which microorganisms can form highly structured multi-species communities in the form of biofilms; one of which is the tooth surface (Dewhirst et al., 2010). Buildup of biofilms in the form of dental plaque is essential for the development of periodontal disease. As subgingival dental plaque accumulates, microbial succession occurs and there is a shift from oral health towards a pathogenic community (Berezow \& Darveau, 2011; Siqueira \& Rocas, 2009). The shift to pathogenic community is thought to be linked to the colonization of key bacteria or "keystone pathogens" (G. Hajishengallis, Darveau, \& Curtis, 2012). $P$. gingivalis, $T$. forsythia, and $T$. denticola are consistently found in the subgingival plaque of patients with periodontal disease and subsequently are 
considered to be periodontal pathogens (Richard P. Darveau, 2010; Holt \& Ebersole, 2005). Evidence for this theory has been seen with $P$. gingivalis and the development of periodontitis. Studies have shown that low levels of P. gingivalis have the ability to change the microbial composition of biofilms through the manipulation of the host immune response thus creating an advantageous environment for microbial growth (George Hajishengallis \& Lambris, 2012; George Hajishengallis et al., 2011; Wang et al., 2010).

Periodontal disease is defined as an inflammatory disease of the periodontal tissue and is categorized as gingivitis and periodontitis. Gingivitis is the mildest form of periodontal disease, characterized by redness, bleeding and inflammation of the gingival tissue. Gingivitis does not cause damage to the connective tissue and is reversible with oral hygiene. Progression of periodontal disease results in periodontitis, characterized by gingival inflammation with damage to the tooth supporting connective tissue causing attachment loss, formation of a periodontal pocket and alveolar bone loss. Severe periodontitis can result in premature tooth loss (Armitage, 1995; Pihlstrom, Michalowicz, \& Johnson).

The pathogenesis of periodontal disease is determined by the host immune inflammatory response to microorganisms of the subgingival biofilm. Initial response to microbial challenge involves the production of cytokines and chemokines by epithelial cells and other resident cells resulting in vasodilation, recruitment of innate immune cells, and activation of the complement system (Cekici, Kantarci, Hasturk, \& Van Dyke, 2014). Production of pro-inflammatory 
innate immunity cytokines TNF- $\alpha$, IL-1, and IL- 6 have been directly associated to the promotion of periodontal tissue inflammation and alveolar bone reabsorption (G. P. Garlet, 2010). Besides innate immune components, adaptive immunity also plays an important role in periodontal disease progression. Bacterial clearance failure leads to the activation of the adaptive immune system. More specifically, bacterial antigens are presented to naïve T- and B- cells by antigenpresenting cells (APCs) thereby activating their development and differentiation (Cekici et al., 2014). Protective or destructive roles of CD4+ T helper cell subsets in periodontal diseases are controversial. A newly defined CD4+ T helper cell subset, regulatory T cells (Tregs), has been associated in providing protection against periodontal disease inflammation by suppressing pro-inflammatory T helper cell subsets (G. P. Garlet, 2010).

\subsection{CD4+ T CELLS}

$\mathrm{B}$ and $\mathrm{T}$ lymphocytes originate from the bone marrow and are derived from hematopoietic stem cells. While B lymphocytes remain in the bone marrow to mature, T progenitor cells must migrate to the thymus where they can differentiate into two populations, naïve CD4+CD8- cells or CD4-CD8+ cells (Takahama, 2006). CD4+ T cells (helper T cells) are key players in the adaptive immune response through their production of cytokines which mediate B cell activation and antibody production, as well as activation of macrophages and cytotoxic T cells (Alberts B, 2002). Activation of naïve CD4+ T cells for further differentiation and cytokine production requires antigen presentation by APCs 
through MHC molecules to T cell receptors. Naïve CD4+ T cell differentiation can lead to four distinct subsets (Th1, Th2, Th17, and Treg) and is dependent on the production of specific transcription factors, cytokines and co-stimulatory molecules for each population (Jin, Sun, Yu, Yang, \& Yeo, 2012). Th1, Th2, and Th17 cells are involved in pro-inflammatory responses to oral microbial challenge. Th17 cells are also closely associated with autoimmune inflammatory diseases. Inversely, regulatory T cells (Tregs) have been shown to regulate and maintain host immune homeostasis by suppressing $\mathrm{T}$ cell proliferation and cytokine production (Cottrez, Hurst, Coffman, \& Groux, 2000).

Activated CD4+ $T$ cells are defined by the cytokines which they produce. Th1 cells are characterized by their production of IL-2 and IFN- $\gamma$ while Th2 cells are known to produce IL-4, IL-5, IL-13, IL-9, and IL-10 notably. In respect to Th17 and Treg cells, IL-17A, IL-17F, and IL-22 are produced by Th17 cells and IL-10 and TGF- $\beta$ are produced by Tregs (Raphael, Nalawade, Eagar, \& Forsthuber, 2015; Zhu, Yamane, \& Paul, 2010). The presence of particular cytokines and transcription factors also plays a role in the induction and identification of different CD4+ T cell subsets. The presence of TGF $\beta$ cytokine is known to promote development of Th17 and Treg cells; however, it has been shown that cytokine IL-6 presence suppresses differentiation away from Treg to Th17, making IL-6 critical for Th17 cell differentiation (Bettelli et al., 2006; Zhou et al., 2007). In addition, orphan nuclear receptor RORyt is a critical Th17 specific transcription factor and its expression is essential in the development and function of Th17 cells (Ivanov et al.; Yang et al.). For Treg cells, transcription 
factor forkhead box P3 (FoxP3) has been found to be the master regulatory gene for Treg cells making it not only critical for development, but expression is also essential in Treg function (Hori, Nomura, \& Sakaguchi, 2003; Sakaguchi, Miyara, Costantino, \& Hafler, 2010). RORyt and FoxP3 are both used as specific markers for Th17 and Treg cell identification respectively.

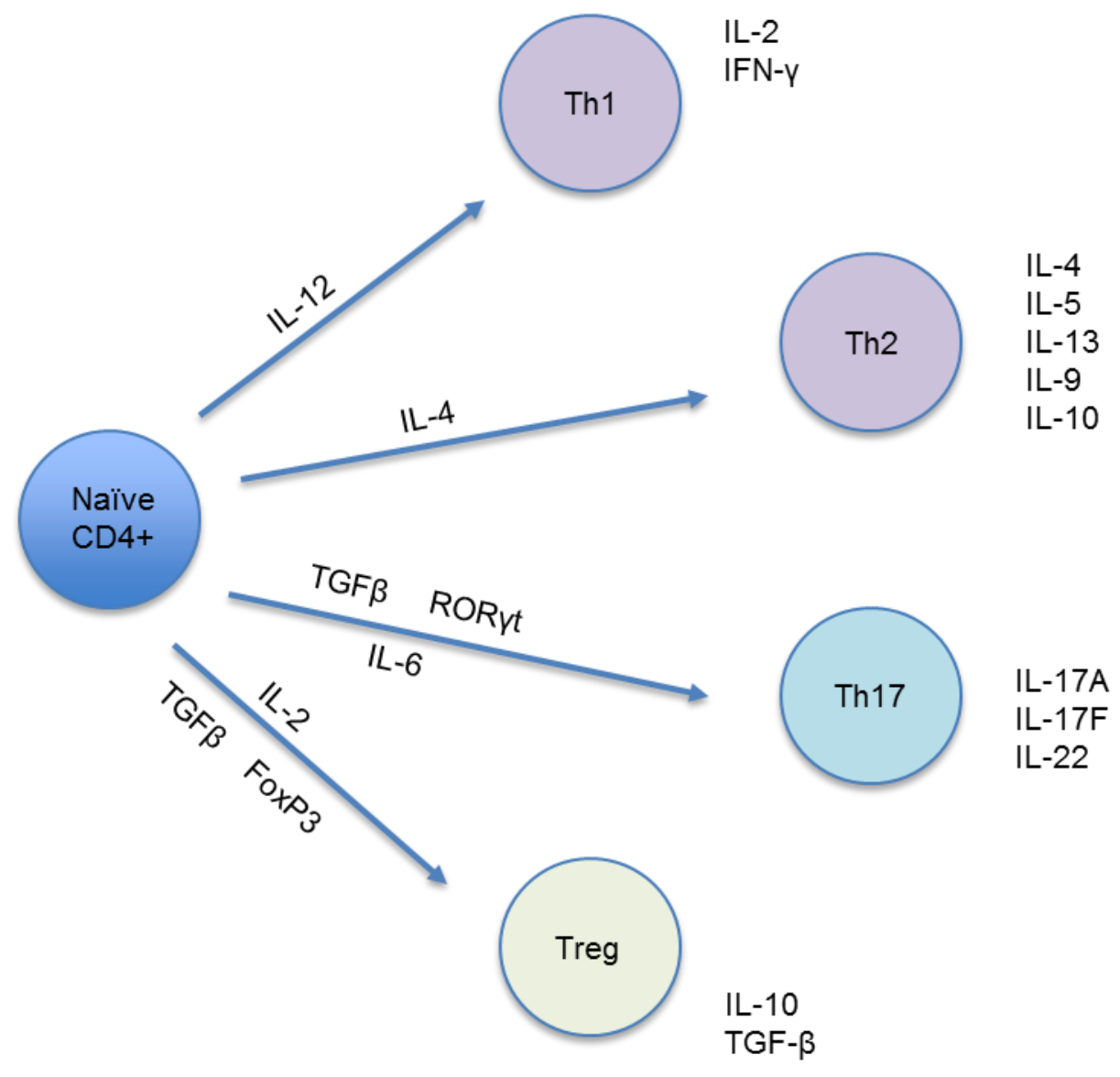

Figure 1. Schematic depiction of CD4+ T cell differentiation. 
CD4+ T cells have been observed to play protective and destructive roles in periodontal disease. For instance, $\mathrm{TH} 1$ cells promote bone resorption through their expression of RANKL and recruitment of RANKL+ cells to periodontal tissues (Repeke et al., 2010). Similarly, Th2 cell cytokines have been associated with progressing periodontal disease by promoting further inflammation and bone resorption; particularly through the expression of IL-6 (Aoyagi, Sugawara-Aoyagi, Yamazaki, \& Hara, 1995; Baker et al., 1999). For newly defined TH17 and Treg cells, more recent studies have helped unravel the roles they play in periodontal disease development and progression. High expression of IL-17, a Th17 related cytokine, has been found in the gingival tissue of periodontal disease patients and is associated with increased severity of periodontal tissue damage and bone loss (reviewed in (W.-C. Cheng, Hughes, \& Taams, 2014)). Conversely, Foxp3+ Treg cells attenuate inflammation and bone resorption and express antiinflammatory cytokine II-10 which has been proposed to regulate II-17 expression in periodontal disease (Gustavo P. Garlet et al., 2010; Moretti et al., 2015).

\subsection{REGULATORY T CELLS IN PERIODONTAL DISEASE}

Treg cell suppressive function in regulating immune homeostasis must be finely tuned. In response to microbial challenges, excessive Treg function can lead to down regulated immune protection causing chronic infection; while suppressed Treg function may result in an increased protective immune response leading to excessive inflammation and possible tissue damage (Richert-Spuhler \& Lund, 2015; Smigiel, Srivastava, Stolley, \& Campbell, 2014). 
In chronic inflammatory diseases, such as periodontal disease, CD4+Foxp3 Treg cells may play an important role in preventing excessive tissue damage and bone loss. Indication of this is seen with the marked presence of Tregs in periodontal lesions as well as increased Treg proliferation stimulated by the presence of oral pathogen P. gingivalis (Cardoso et al., 2008; Kobayashi et al., 2011; Nakajima et al., 2005). Upregulation of Tregs in periodontal tissue coinciding with increased production of anti-inflammatory IL-10 cytokine further indicates Treg protective role by mediating inflammatory responses to oral pathogens (Kobayashi et al., 2011). In fact, inhibition of Treg function resulted in increased inflammation and alveolar bone loss in mice with periodontal disease (Gustavo P. Garlet et al., 2010). Furthermore, production of Treg related cytokine, IL-10, has been shown to be involved in maintaining alveolar bone homeostasis and its absence results in increased bone loss (Claudino et al., 2010). A disruption in Treg regulation in periodontal disease may lead to increased severity resulting in greater periodontal tissue damage, attachment loss and alveolar bone loss.

\subsection{PERIODONTAL DISEASE DURING PREGNANCY}

During pregnancy women are susceptible to periodontal tissue inflammation with $35-100 \%$ of pregnant women developing gingivitis (Gürsoy, Pajukanta, Sorsa, \& Könönen, 2008). In most instances, it was reported that gingival inflammation did not cause periodontal attachment loss and that effects were reversible after pregnancy (Tilakaratne et al., 2000b; Wu, Chen, \& Jiang, 2015). However, recent reports have shown that gingival inflammation during 
pregnancy can cause severe attachment loss in some patients (Lachat, Solnik, Nana, \& Citron, 2011). In addition, studies have demonstrated there may be an association between periodontal disease during pregnancy and adverse pregnancy outcomes such as preterm birth and/or low birth weight (Chambrone, Guglielmetti, Pannuti, \& Chambrone, 2011; Macedo et al., 2014; Perunovic et al., 2015). Despite being well documented, the etiology of pregnancy gingivitis is still not clearly defined.

It is believed that fluctuations in pregnancy hormone levels are in part responsible for increased gingival inflammation during pregnancy; however, its exact mechanism is not fully determined. Studies have shown an association between changes in estrogen and progesterone levels with shifts in the regulation of immune cells (Pazos, Sperling, Moran, \& Kraus, 2012). For T helper cells, the number of CD4+ cells tended to increase while CD4+Foxp3+ T regulatory cell number decreased systemically during the $2^{\text {nd }}$ and $3^{\text {rd }}$ trimesters of pregnancy (Mjosberg et al., 2009; Raber-Durlacher, Leene, Palmer-Bouva, Raber, \& Abraham-Inpijn, 1993). Changes in the number of CD4+ T cells coincided with reports of increased numbers of subgingival micro-organisms and increasing gingival inflammation as pregnancy progressed into the $2^{\text {nd }}$ and $3^{\text {rd }}$ trimester (Laine, 2002a; Wu et al., 2015).

Changes in the subgingival microbial composition during pregnancy have also been proposed to contribute to the development of exacerbated gingival inflammation. In the $2^{\text {nd }}$ and $3^{\text {rd }}$ trimesters, increased presence of periodontal oral pathogens have been observed. Notably, $P$. gingivalis, 
A. actinomycetemcomitans, and $P$. intermedia were found to have the greatest increase in pregnant women (Borgo, Rodrigues, Feitosa, Xavier, \& AvilaCampos, 2014; Ana Carrillo-de-Albornoz, Figuero, Herrera, \& BasconesMartínez, 2010; Emmatty, Mathew, \& Kuruvilla, 2013). However, some studies have found that differences in certain oral pathogen number were not significantly different between pregnant and non-pregnant women (Adriaens, Alessandri, Spörri, Lang, \& Persson, 2008), but an association was found between more severe gingival inflammation and the presence of certain oral pathogens (Ana Carrillo-de-Albornoz et al., 2010). Despite contradictory reports, it is established that plaque is necessary to induce gingival inflammation during pregnancy and removal of plaque with an intense oral hygiene regimen can help reduce gingival inflammation severity (Arafat, 1974; Geisinger et al., 2014; Kaur et al., 2014)

\section{HYPOTHESIS}

Women may experience varying degrees of gingival inflammation during pregnancy. Although clinically well documented, its etiology remains elusive. The presence of periodontal pathogens has been correlated with the development of gingival inflammation; however, it is unclear why some women develop more severe inflammation leading to periodontal tissue damage and alveolar bone loss. A possible contributing factor is the systemic shift of immune cell populations due to fluctuating pregnancy hormones. One affected population that is critical for immune hemostasis is CD4+Foxp3+ Treg cells. Serum samples 
taken from pregnant women indicate that Treg development is down regulated in the $2^{\text {nd }}$ and $3^{\text {rd }}$ trimesters. Treg cells have been shown to infiltrate periodontal lesions and reduce inflammatory periodontal tissue damage and alveolar bone loss. We hypothesize that in response to oral pathogen stimulus, gingival Treg development is suppressed during pregnancy, which may be associated with exacerbated gingival inflammation and periodontal tissue damage. 


\section{CHAPTER 2: METHODS AND MATERIALS}

\subsection{PREGNANCY PERIODONTAL DISEASE MODEL}

In order to effectively investigate Treg role in periodontal disease during pregnancy we developed a pregnancy gingival inflammation murine model. By adopting a more intensified ligature-induced inflammatory periodontal disease model, we are able to induce gingival inflammation in pregnant mice within the short mouse gestational period of 18-20 days. In our model, female C57BL/6 mice are paired with BALB/c males and checked for vaginal plugs, indicating copulation. Upon appearance of vaginal plugs (day 0 of gestation), female mice are separated from the males. At day 6 of gestation, a ligation around the $2^{\text {nd }}$ maxillary molar, consisting of $6-0$ silk suture, is placed in the gingival sulcus of female mice. Mice are then infected with $1 \times 10^{9}$ colony-forming units of $P$. gingivalis ATCC33277 at the time of ligation and subsequently every other day up to day 18 of gestation. On day 18 of gestation, the experiment is terminated. In our experiments we maintained four groups: Pregnant mice with induced periodontal disease (ligation with $P g$ infection), Pregnant control (No ligation or $P g$ infection), Non-pregnant mice with induced periodontal disease, and Nonpregnant control. All animal experiments were approved by the University of Louisville Institution Animal Care and Use Committee 


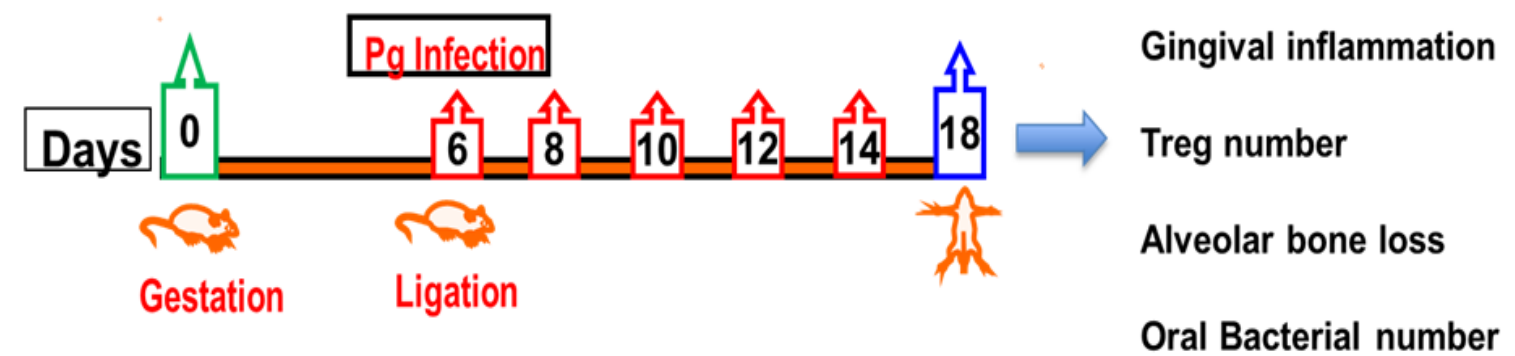

Figure 2. Schematic depiction of ligation induced periodontal disease during pregnancy. Ligation around maxillary molar with $P g$ infection will induce inflammation and tissue damage in pregnant mice in a shorter and specific period.

\subsection{RNA ISOLATION AND QUANTITATIVE REVERSE TRANSCRIPTION-PCR}

We harvested maxillary gingiva from infection induced pregnant/nonpregnant and control pregnant/non-pregnant mice. Gingival tissue was immersed in RNAlater ${ }^{\circledR}$ (Ambion Cat \# AM7020) and kept at $4^{\circ} \mathrm{C}$ overnight; then stored at $-20^{\circ} \mathrm{C}$ until further isolation of RNA. Gingival tissue was placed in RLT buffer (with beta-mercaptoethanol) and disrupted by a homogenizer. After homogenization, lysate was centrifuged and supernatant was conserved. RNeasy® mini kit (QIAGEN Cat \# 74104) was used to isolate RNA from supernatant and DNase treatment was performed using RNase Free DNase Set 
(QIAGEN Cat \# 79254). Concentration of isolated RNA was measured with a NanoDrop spectrophotometer. $4 \mu \mathrm{g}$ of RNA was used from each sample for cDNA synthesis. High capacity cDNA Reverse Transcription Kit (Applied Biosystems Cat \# 4368814) was used for the RT-PCR reaction. RNA was quantitatively determined by real-time PCR using an ABI 7500 System (Applied Biosystem).

\subsection{LYMPHOCYTE ISOLATION AND QUANTIFICATION BY FLOW CYTOMETRY}

We harvested the cervical lymph nodes from infection induced pregnant/non-pregnant and control pregnant/non-pregnant mice. Lymph nodes were smashed in $2 \mathrm{ml}$ of Magnetic-activated cell sorting (MACS) buffer to release lymphocytes, followed by filtration through a cell strainer. Cells were counted and re-suspending in MACS to achieve $1 \times 10^{6}$ cells $/ \mathrm{ml}$ concentration. $100 \mu \mathrm{l}$ of cell suspension was transferred to a new tube and cells were stained for cell surface antigens with fluorescent-conjugated anti-CD3-APC and CD4-Percp (eBioscience) for 20 minutes and then washed. Foxp3 fixation/permeabilization working solution was added to cells and incubated in the dark at $4^{\circ} \mathrm{C}$ for at least 30 min or up to 18 hours in solution. After incubation, cells were washed and resuspended in $100 \mu$ l of $1 \mathrm{X}$ Permeabilization buffer. Cells were then stained with $1.5 \mu \mathrm{l} / 50 \mu \mathrm{l}$ fluorescent-conjugated anti-Foxp3 antibody and incubated in the dark for $30 \mathrm{~min}$ at room temperature. After incubation cells were washed, resuspended in $200 \mu \mathrm{l}$ MACS buffer and analyzed by flow cytometry. The 
percentage of $\mathrm{CD} 3+\mathrm{CD} 4+\mathrm{Foxp} 3+$ (Treg) cells in CD3+CD4+ (Th) cells population was determined.

\subsection{ORAL BACTERIA QUANTIFICATION}

The oral cavity of each animal was sampled on day 18 of gestation (experiment termination date) with a sterile cotton swab. Swab samples were vortexed in $1000 \mu$ l of phosphate-buffered saline (PBS). Serial dilution of the bacterial suspension to $10^{-2}, 10^{-3}$, and $10^{-4}$ was conducted. Aliquots $50 \mu$ l of each dilution were plated onto blood agar plates. Bacterial plates were incubated anaerobically at $37^{\circ} \mathrm{C}$ for one week. Bacterial colonies were then counted to determine CFU.

\subsection{ALVEOLAR BONE LOSS QUANTIFICATION}

Horizontal bone loss around the maxillary molars was determined morphometrically by measuring the distance between the cementoenamel junction (CEJ) and alveolar bone crest (ABC). Skulls or hemisected mandibles were boiled for $10 \mathrm{~min}$ at a pressure of $15 \mathrm{Lb} / \mathrm{in}^{2}$ and then defleshed. They were immersed overnight in $3 \%$ hydrogen peroxide, pulsed for $1 \mathrm{~min}$ in $1 \%$ bleach, washed and air dried. They were then stained with $0.5 \%$ eosin for 5 minutes followed by $1 \%$ methylene blue for 1 minute. Skulls were washed well after staining and air dried. Measurements were obtained at seven sites on the buccal side of the left and right maxillary molars. A total of 14 buccal site measurements 
per mouse were obtained for the distance from (CEJ to $A B C)$. These measurements were made under a dissection microscope $(x 40)$ fitted with a video image marker measurement system (model VIA 170; Boeckeler Instruments, Inc., Tucson, Ariz.); it is standardized to give measurements in millimeters. The amount of change in the alveolar bone for each individual mouse was calculated by subtracting the $\mathrm{CEJ}$ to $\mathrm{ABC}$ distance for that mouse from the mean CEJ-ABC distance for each corresponding control group.

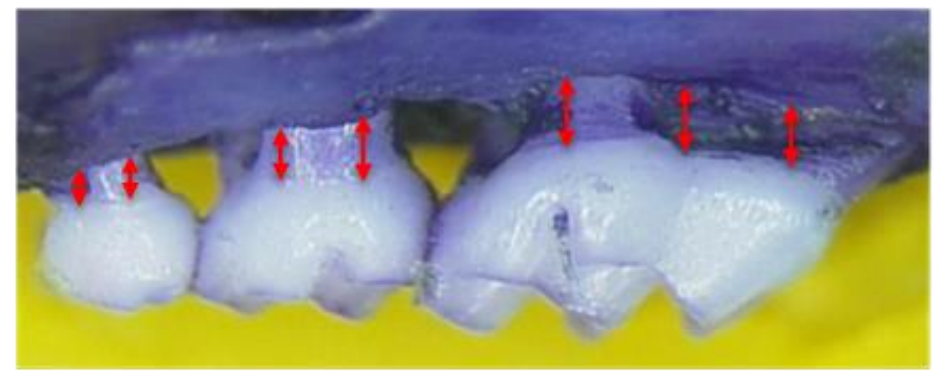

Figure 3. Eosin methylene blue staining on maxillary jaw bone with depiction of 7 CEJ-ABC measurement sites. 


\section{CHAPTER 3: RESULTS}

\subsection{LIGATION WITH P. GINGIVALIS INFCTION INDUCED HIGHER PRO- INFLAMMATORY CYTOKINE EXPRESSION IN PREGNANT MICE}

It is well known that pregnant women tend to develop gingival inflammation and this symptom is commonly referred to as pregnancy gingivitis. In order to understand the pathogenesis of the disease, we established a murine model to induce gingival inflammation by ligating the second molar of the mice (described in Methods and Fig. 2). Reports showed that $P$. gingivalis was found in pregnant women with gingivitis (A. Carrillo-de-Albornoz, Figuero, Herrera, \& Bascones-Martinez, 2010; Kornman \& Loesche, 1980; Laine, 2002b; RaberDurlacher, van Steenbergen, Van der Velden, de Graaff, \& Abraham-Inpijn, 1994). Therefore, we infected the pregnant mice with $P$. gingivalis ATCC 33277 after ligation and infected again every other day (Fig. 4A). The experiment was terminated at day 18 of gestation (mouse gestation usually lasts $19-21$ days). At the termination of experiment, gingival tissues were harvested and assessed for the pro-inflammatory cytokine expression, after removal of the ligatures, which remained in place in all mice throughout the experimental period (day 6-18 of gestation). We tested the gingival expression of IL-1 $1 \beta$, which is elevated in periodontal disease patients and was shown to drive periodontal disease in 
animal models. Ligation and Pg infection induced IL-1 $1 \beta$ expression in both pregnant mice and non-pregnant mice, compared with their non-ligated counterparts. Higher IL-1 $\beta$ expression was detected in pregnant mice (Fig. 4A). IL-17 is an important pro-inflammatory and bone-resorption cytokine expressed by both innate and adaptive immune cells, such as CD4+Th17 cells (Weaver, Hatton, Mangan, \& Harrington, 2007). Previous reports showed that IL-17 is critical in inflammatory periodontal disease (Eskan et al., 2012). IL-17 expression is dramatically upregulated in both infection-induced pregnant and non-pregnant mice. Furthermore, IL-17 is expressed at significantly higher levels in infectioninduced pregnant mice than non-pregnant mice. Besides IL-1 $\beta$ and IL-17, IL-6 and TNF $\alpha$ are also important indicators of inflammation. They are expressed in periodontal disease patients at high levels and advance disease progression (Assuma, Oates, Cochran, Amar, \& Graves, 1998; Masada et al., 1990; Rossomando, Kennedy, \& Hadjimichael, 1990). Our results showed that IL-6 and TNF $\alpha$ are expressed higher in both ligated pregnant mice and non-pregnant mice; however, expression of TNFa and II-6 did not differ between infection induced pregnant and non-pregnant mice.

In another set of experiments, we ligated the mice only (without $P$. gingivalis infection; Normal Flora Only), in order to understand the role of $P g$ in the exacerbated gingival inflammation. We found that ligation induced proinflammatory cytokine production, but there was no significant difference between pregnant and non-pregnant mice that were ligated and not infected with 
$\mathrm{Pg}$ (Fig. 4B). Presence of oral pathogen infection in conjunction with ligation is necessary to induce exacerbated inflammation during pregnancy.

A

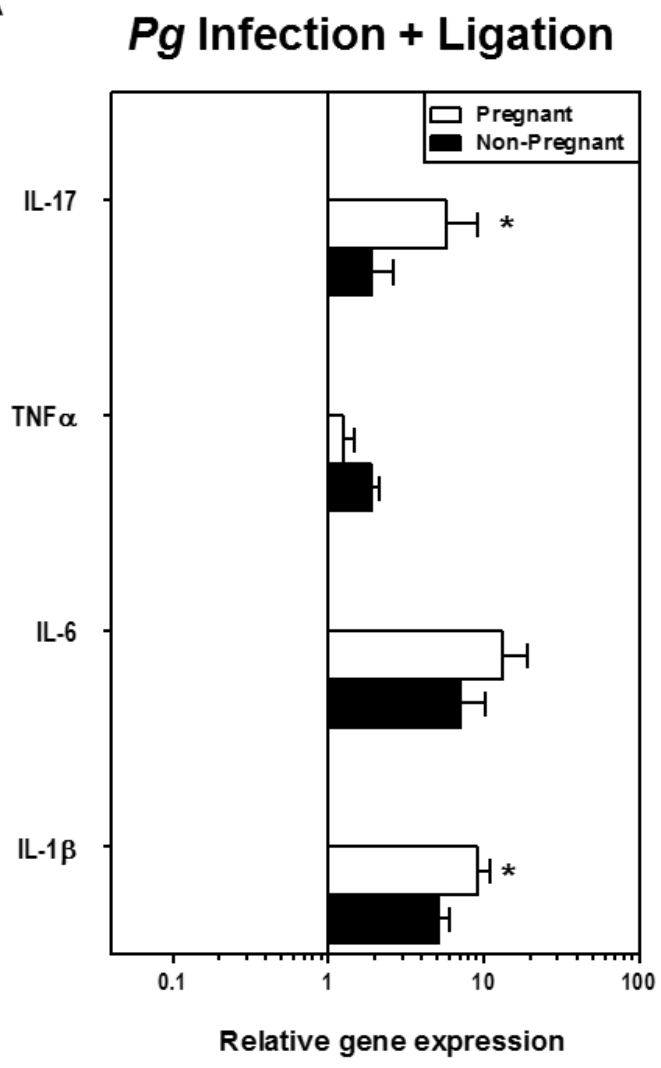

B

\section{Normal Flora + Ligation}

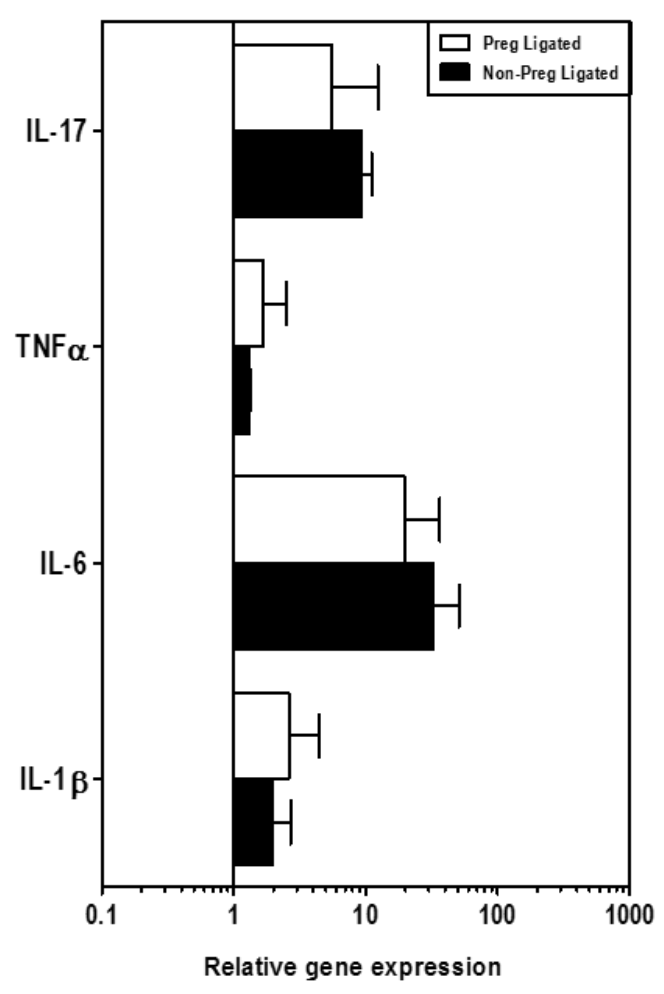

Figure 4. Higher expression of pro-inflammatory cytokines in the gingivae of ligated pregnant compared to non-pregnant mice with $P$. gingivalis infection. Eight to 10 weeks old pregnant or non-pregnant C57BL/6 mice were ligated and with A) Pg ATCC33277 infection or B) No infection (Normal Flora Only). Results are shown as fold change relative to pregnant and non-pregnant sham-ligated mice, respectively. Each data point represents the mean \pm SD of 5 separate 
expression values, corresponding to $\mathrm{qPCR}$ analysis of individual mice. Asterisks indicate statistically significant $(p<0.05)$ differences between pregnant and nonpregnant mice.

\subsection{GREATER ALVEOLAR BONE LOSS IN P. GINGAVLIS INFECTED MICE}

While in most pregnancy gingivitis patients, the inflammation will wane after pregnancy (Cohen, Shapiro, Friedman, Kyle, \& Franklin, 1971; Gursoy, Pajukanta, Sorsa, \& Kononen, 2008; Tilakaratne et al., 2000a), some reports showed that this inflammation lead to periodontal tissue destruction during pregnancy in some patients (Christensen, Gaist, Jeune, \& Vaupel, 1998; Lieff et al., 2004; Machuca, Khoshfeiz, Lacalle, Machuca, \& Bullon, 1999; Moss, Beck, \& Offenbacher, 2005; Taani, Habashneh, Hammad, \& Batieha, 2003). After confirming increased gingival inflammation in infection-induced pregnant mice, we then examined if the more severe inflammation will induce greater alveolar bone loss. Horizontal measurements of buccal CEJ and ABC distance (Fig. 3) were taken. Ligation with infection induced bone loss in both pregnant and nonpregnant mice, while greater bone loss was induced in the pregnant mice than the non-pregnant mice. $C E J / A B C$ readings in the non-ligated pregnant mice and non-pregnant mice were similar ( $p<0.001$; Fig. 5A).

In another set of experiments with only ligation but without $\mathrm{P}$. gingivalis infection (Normal Flora Only), we found that ligation induced alveolar bone loss, 
but there was no significant difference between pregnant and non-pregnant mice (Fig. 4B). The presence of oral pathogen infection in conjunction with ligation is necessary to induce exacerbated bone loss in during pregnancy.
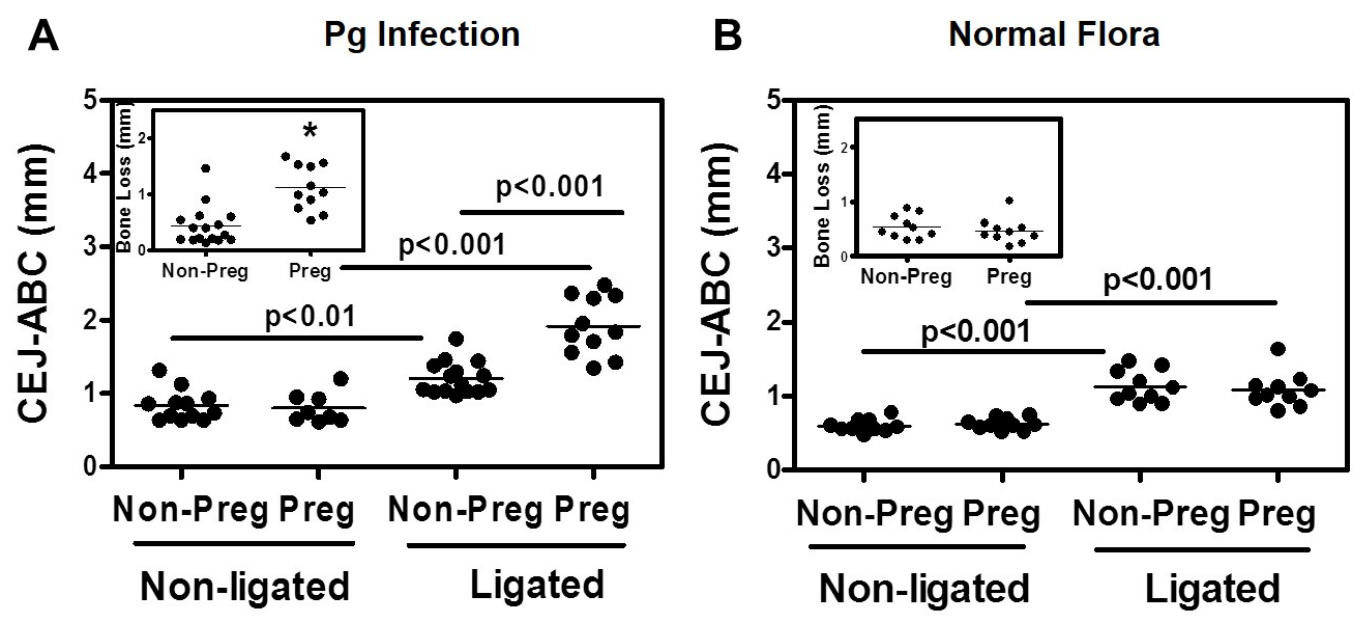

Figure 5. Ligation with $\mathrm{Pg}$ infection causes more severe bone loss in pregnant mice than non-pregnant mice. Eight to 10 weeks old pregnant or nonpregnant C57BL/6 mice were ligated and with A) Pg ATCC33277 infection or B) No infection (Normal Flora Only). Sham-ligated and sham-infected mice were used as controls (Non-ligated). Upper jaws were harvested and measured for CEJ-ABC distance at 7 most affected maxillary buccal sites and the readings were totaled for each mouse. The CEJ-ABC reading of each mouse was represented by each dot. P-values between the groups were labeled. Bone loss was calculated by subtracting the total CEJ-ABC distance for the ligated mice from the total CEJ-ABC 
distance of the non-ligated mice. Asterisks indicate statistically significant $(p<$ 0.05) differences between pregnant and non-pregnant groups.

\subsection{DECREASED EXPRESSION OF TREG RELATED MOLECULES IN INFECTION-INDUCED PREGANANT MICE}

Treg cells have been observed to play an immunosuppressive role in periodontal disease by attenuating inflammation and alveolar bone resorption (Gustavo P. Garlet et al., 2010). Expression of Treg related cytokines such as TGF $\beta$ and II-10 have been linked to suppressing Th1 and Th17 cell development (Gorelik, Constant, \& Flavell, 2002; Li, Wan, \& Flavell; Moretti et al., 2015). We therefore investigated gingival expression of Treg related molecules in pregnant and non-pregnant mice. As described earlier, we induced inflammation and harvested gingiva at day 18 of gestation (methods and Figure 2). We examined the expression of FoxP3, which is a Treg specific transcription factor that is critical for Treg differentiation and function (Hori et al., 2003; Sakaguchi et al., 2010). We detected a significant decrease of Foxp3 expression in infection induced ligated pregnant mice when compared to non-pregnant mice (Fig. 6A). As mentioned, anti-inflammatory cytokines TGF $\beta$ and II-10 are critical for Treg development and function. Expression of TGF $\beta$ can promote Treg differentiation by inducing FoxP3 gene expression (W. Chen et al., 2003) as well as suppress the development of Th1 and Th17 cells (Li et al.; Zhou et al., 2008). Similarly, 
Treg IL-10 signaling suppresses development of Th17 (Huber et al., 2011) and attenuates tissue damage and bone resorption in periodontal disease (Moretti et al., 2015). In infection induced pregnant mice, we detected decreased expression of both TGF $\beta$ and IL-10 compared to non-pregnant mice (Figure 4A). In examining expression of Treg surface receptors, we noted a lower expression of CTLA-4 and CD28 as well as their ligands, CD80 and CD86, in infection induced pregnant mice (Figure 4A). CTLA-4 and CD28 and their respective ligands CD80 and CD86 are important in Treg development and regulation (Guo, Iclozan, Suh, Anasetti, \& Yu, 2008; Read et al., 2006; Zheng et al., 2004). In a separate experiment we again tested ligated only mice (no Pg infection). We observed no significant difference in the expression of Treg related molecules between pregnant and non-pregnant mice (Figure 4B), indicating that $P g$ infection is important for the different expression of Treg related molecules during pregnancy. 
A

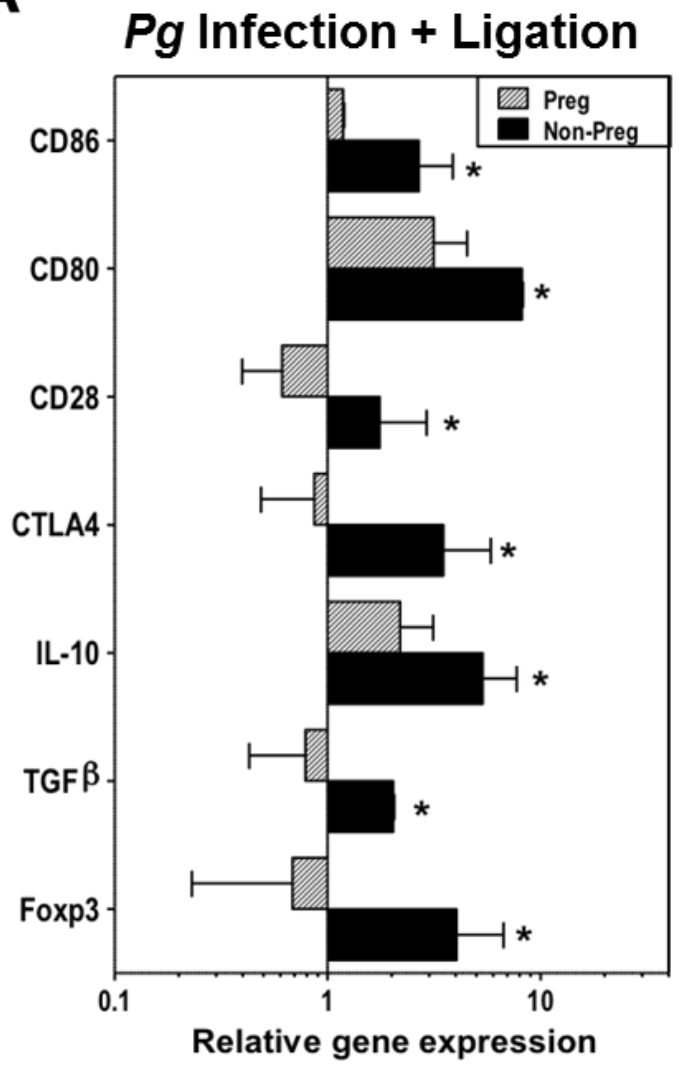

B

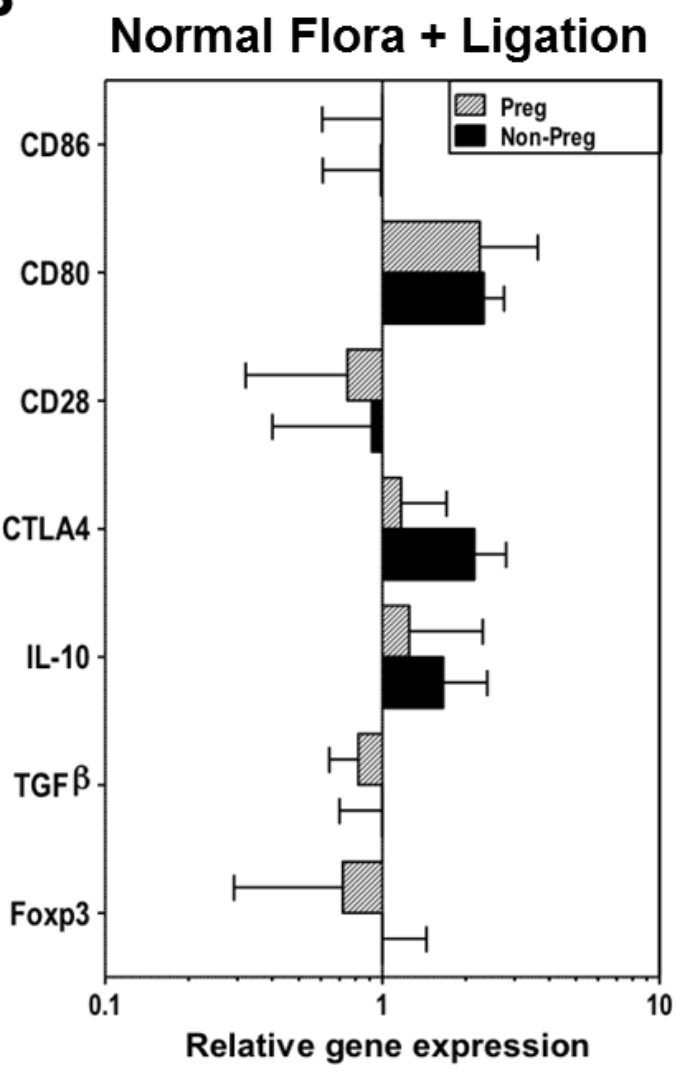

Figure 6. Decreased expression of Treg-related cytokines and molecules in the gingivae of ligated pregnant mice compared to non-pregnant mice with P. gingivalis infection. Eight to 10 week old pregnant or non-pregnant C57BL/6 mice were ligated and with A) Pg ATCC33277 infection or B) No infection (Normal Flora Only). Results are shown as fold change relative to pregnant and nonpregnant sham-ligated mice, respectively. Each data point represents the mean \pm SD of 5 separate expression values, corresponding to qPCR analysis of individual mice. Asterisks indicate statistically significant $(p<0.05)$ differences between pregnant and non-pregnant mice. 


\subsection{LOWER PERCENTAGE OF TREG CELLS IN CD4+ T CELL POPULATION}

IN DRAINING LYMPH NODES OF INFECTION-INDUCED PREGNANT MICE

During pregnancy, women undergo shifts in immune cell regulation to prevent fetal rejection. Levels of circulating FoxP3+ Treg cells have been observed to vary at different points during pregnancy with an initial increase in the 1st trimester followed by a decrease in the 2nd trimester (Mjosberg et al., 2009). Decrease in circulating Treg cells coincides with observed onset of gingival inflammation in pregnant women (Laine, 2002a; Wu et al., 2015). In order to investigate if the number of periodontal infection induced Tregs are reduced during pregnancy we examined the percentage of CD4+FoxP3+ T cells in CD4+ T cell population in the oral cavity draining lymph nodes. At experiment termination (day 18 of gestation), we harvested the cervical lymph nodes of infection induced pregnant/non pregnant mice and their non-ligated counterparts. Cells retrieved from cervical lymph nodes were stained for Treg markers, CD3, CD4 and Foxp3; then analyzed by flow cytometry. In identifying T cells within the cell population extracted from lymph nodes, we gated on CD3 and CD4 positive cells. We then determined the number of Treg cells from CD3+CD4+ T cell population by Foxp3 expression. We found an overall increase of FoxP3+ Treg cells in mice that were ligated and infected with $\mathrm{Pg}$ compared to their control counterparts (Figure 7). This coincides with previous reports of $P$. gingivalis induced Treg cell proliferation and observed presence of Tregs in periodontal tissues (Cardoso et al., 2008; Kobayashi et al., 2011; Nakajima et al., 2005). In 
comparing infection induced pregnant and non-pregnant mice, lower percentage of Treg cells were found in pregnant mice (Figure 7).

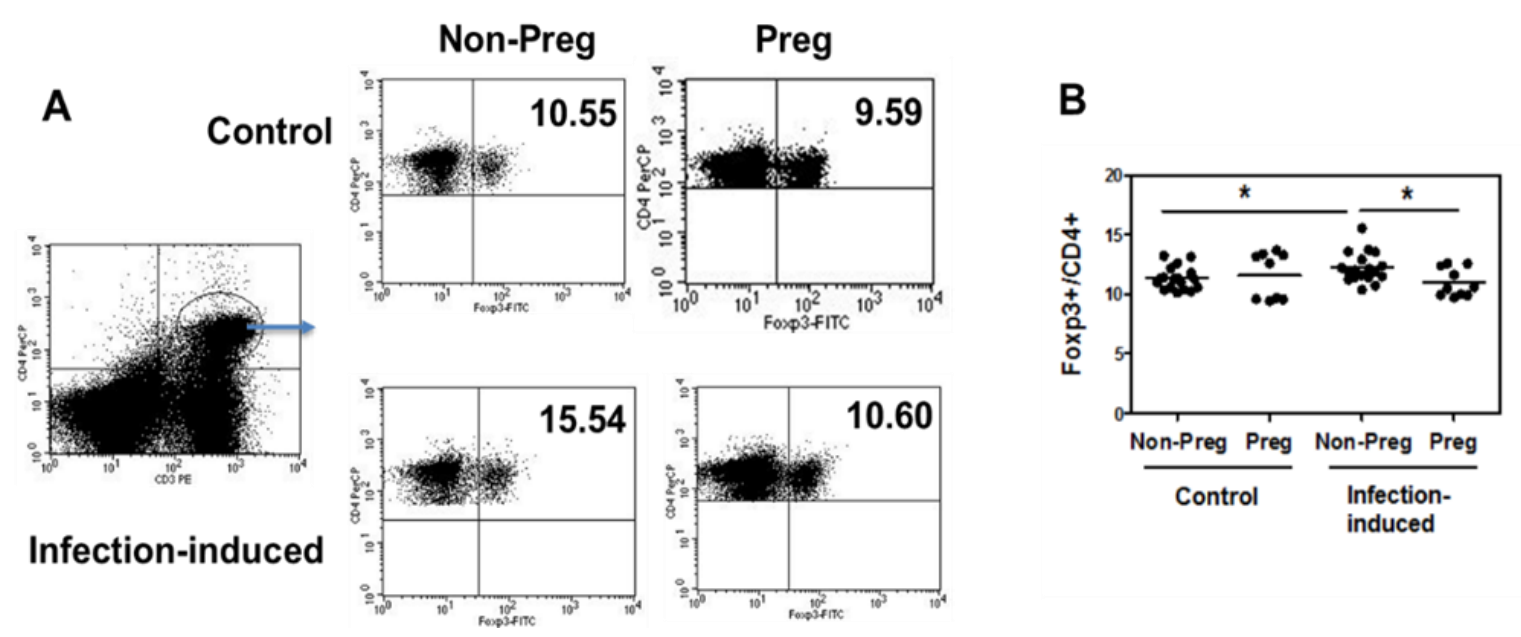

Figure 7. Decreased percentage of Treg cells in ligated and $\mathrm{Pg}$ infected pregnant mice than non-pregnant mice. Cervical LNs were harvested from pregnant (Preg) and non-pregnant (Non-Preg) C57/BL6 mice after ligation. Mice that went under sham ligation were used as controls. Cells from the LNs were stained with fluorescence-conjugated CD3, CD4, and FoxP3 antibodies and tested on Flow Cytometer (A). Percentage of CD4+Foxp3+ cells in CD4+ cells were determined (B). The reading of each mouse was represented by each dot. Asterisks indicate statistically significant $(p<0.05)$ differences between pregnant and non-pregnant mice. 


\subsection{INCREASED PERCENTAGE OF TH17 CELLS IN PREGNANT MICE}

Th17 cells are strongly associated with inflammatory diseases and are involved in host immune response to microbial challenges. In periodontal disease, studies have found presence of Th17 cells in periodontal tissues as well as increased expression of IL-17 (Adibrad et al., 2012; Cardoso et al., 2008). Since our previous results also indicated an increase of IL-17 expression in the gingival tissue of infection induced mice, we then examined the percentage of Th17 cells in the draining lymph nodes. Cells harvested from the cervical lymph nodes were stained for CD3, CD4 and RORyt and then analyzed by flow cytometry. RORyt is a Th17 specific transcription factor and its gene expression is critical for Th17 differentiation (Ivanov et al.; Yang et al.). In identifying Th17 cells, we initially gated on CD3 and CD4 positive cells and then on RORyt expression. In comparing infection induced mice to their control counterparts, we observed an increase of Th17 in both pregnant and non-pregnant mice. However, when comparing infection induced pregnant and non-pregnant, there was modestly greater number of Th17 cells in pregnant mice (Fig. 8). 


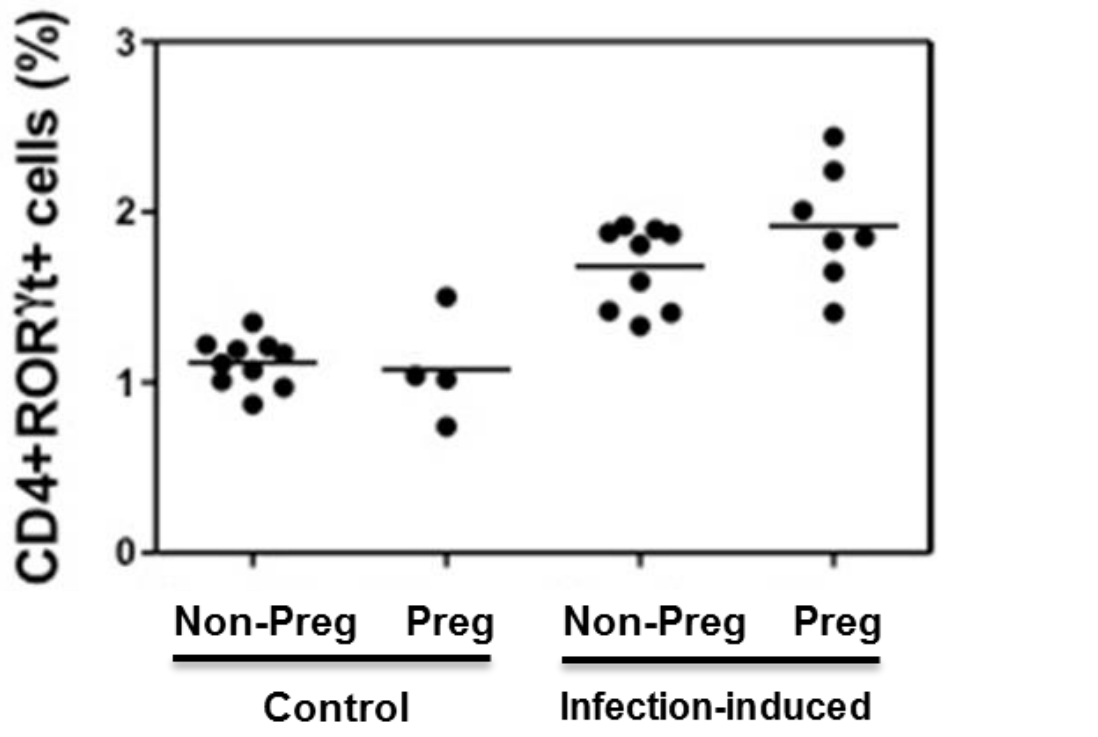

Figure 8. Increased percentage of Th17 cells in ligated and Pg infected pregnant mice than non-pregnant mice. Cervical LNs were harvested from pregnant (Preg) and non-pregnant (Non-Preg) C57/BL6 mice after ligation. Mice that went under sham ligation were used as controls. Cells from the LNs were stained with fluorescence-conjugated CD3, CD4, and RORyt antibodies and tested on Flow Cytometer. Percentage of CD4+ RORyt+ cells in CD4+ cells were determined. The reading of each mouse is represented by each dot. 


\subsection{REDUCED ORAL BACTERIA CLEARANCE}

Our previous results clearly show that during pregnancy, Treg development is reduced (Fig. 6 and Fig. 7) while inflammation (Fig. 4) and Th17 cell development (Fig. 8) is increased; indicating disrupted Treg regulatory function on inflammatory adaptive immune response to oral pathogens. We next questioned if decreased Treg cell presence and regulatory effect on inflammatory response to oral pathogens resulted in greater oral bacteria clearance. In order to examine the effects on oral bacteria numbers, oral swabs were taken from mice at experiment termination (day 18 of gestation). Bacteria was suspended in $1 \mathrm{x}$ PBS and plated on blood agar plates. Bacterial plates were then incubated for one week in an anaerobic chamber, after which colonies were counted to determine CFU. We observed an increase in number of oral bacteria in infection induced mice compared to their control counterparts. When comparing between infection-induced pregnant mice to non-pregnant mice, we found there to be significantly greater number of oral bacteria in pregnant mice (Figure 9). Despite a decrease in the number of Treg cells, oral bacteria clearance was not enhanced in pregnant mice. 


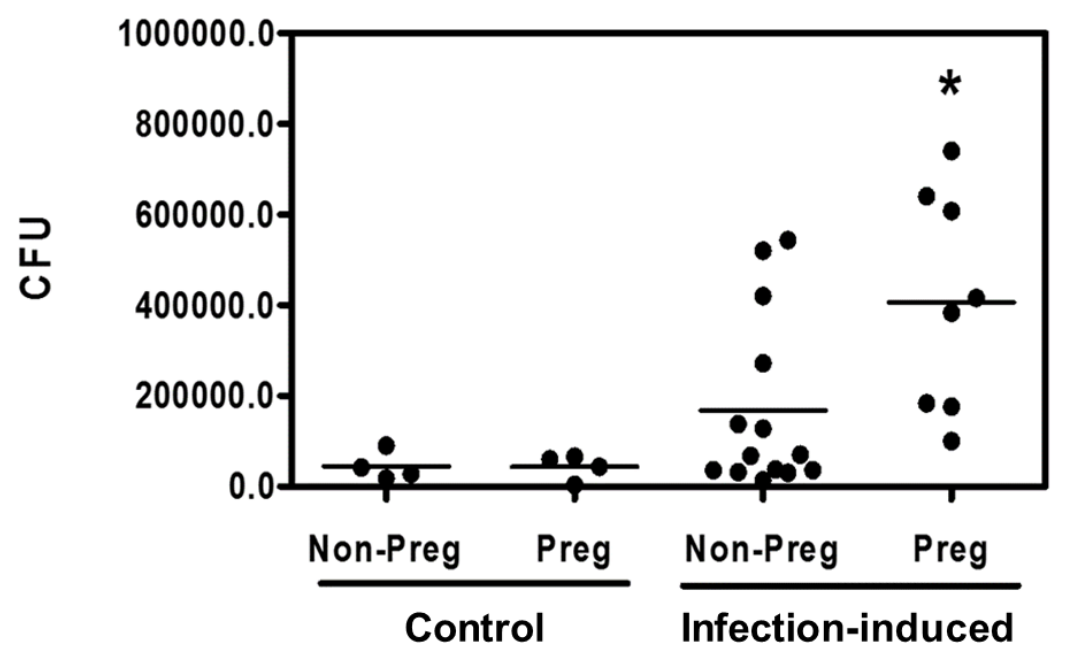

Figure 9. Infection-induced pregnant mice have greater number of oral bacteria compared to non-pregnant mice. CFU determined by anaerobic culture of oral swabs. The reading of each mouse is represented by each dot. Asterisks indicate statistically significant $(p<0.05)$ differences between pregnant and nonpregnant mice. 


\section{CHAPTER 4: DISCUSSION}

During pregnancy, women are prone to developing gingival inflammation with some women experiencing sever inflammation, periodontal tissue damage and alveolar bone loss. The mechanism by which pregnancy induces exacerbated gingival inflammation is not fully understood. However, previous research has indicated that changes in immune regulation due to hormonal fluctuations may be associated. We have focused our study on examining the regulation of Treg cells in periodontal disease during pregnancy.

To study Treg regulation, we developed a modified mouse model in which we induced periodontal disease in pregnant mice (methods and Fig.1). To ensure our model mimicked clinical pregnancy gingival inflammation, we compared the level of gingival pro-inflammatory cytokine mRNA expression of pregnant mice to non-pregnant mice. Our results indicated an increase of proinflammatory cytokine expression in infection induced pregnant mice (Fig. 4A), confirming development of exacerbated gingival inflammation. We also investigated if ligation alone (no P. gingivalis infection) would induce gingival inflammation; however, there was no significant difference in cytokine expression between pregnant and non-pregnant mice indicating that presence of oral 
pathogens is necessary for increased inflammation (Fig. 4B). This is in agreement with periodontal pathogens presence found in the analysis of subgingival microbial composition of pregnant women who experienced increased gingival inflammation (Borgo et al., 2014; A. Carrillo-de-Albornoz et al., 2010; Emmatty et al., 2013). As a result of exacerbated gingival inflammation, some women developed permanent periodontal tissue damage and alveolar bone loss (Christensen et al., 1998; Lieff et al., 2004; Machuca et al., 1999; Moss et al., 2005; Taani et al., 2003). In our model, infection induced pregnant mice also exhibited greater alveolar bone loss (Fig. 5A), consistent with clinical observations.

$P$. gingivalis is one of the most widely investigated periodontal pathogen. It is considered to be a keystone pathogen and is associated with the development of periodontal disease (Richard P. Darveau, 2010; R. P. Darveau, Hajishengallis, \& Curtis, 2012; G. Hajishengallis et al., 2012). Studies have revealed a complicated relationship between $P$. gingivalis and the host innate immune response. $P g$ can manipulate the host immune response and evade bacterial clearance (George Hajishengallis, Krauss, Liang, McIntosh, \& Lambris, 2012; Maekawa et al., 2014). This interaction is proposed to create a favorable environment for microbial colonization thus contributing to dysbiosis and the disruption of host immune homeostasis (Richard P. Darveau, 2010; George Hajishengallis et al., 2012). Despite being well studied, much remains unknown on the mechanisms in which $P g$ instigates periodontal disease. 
In investigating the association between Treg regulation and periodontal disease during pregnancy, we examined the number of Treg cells in the draining lymph nodes and expression of Treg related molecules in gingival tissue. Infection-induced pregnant mice were found to have reduced Treg cell number (Fig. 7) as well as decreased expression of Treg related molecules that are pertinent to its differentiation and function (Fig. 6A). Notably, critical Treg differentiation molecules Foxp3 and TGF $\beta$ showed dramatic decreases in pregnant mice indicating suppressed Treg cell differentiation. Further evidence of downregulated Treg development is observed in the marked reduction of Treg surface receptors CTLA-4 and CD28 (Fig. 6A). Disruptions in Treg homeostasis can lead to disease or increased severity of disease. In the case of periodontal disease, Treg cells are associated with reducing periodontal tissue damage and alveolar bone loss by suppressing $\mathrm{T}$ cell inflammatory responses to oral microbial challenge. Garlet et al. (2010) demonstrated that inhibition of Treg cells caused greater tissue damage and inflammation induced bone resorption (Gustavo P. Garlet et al., 2010). Similarly, our study showed decreased Treg number and molecule expression during pregnancy accompanied by increased gingival inflammation and alveolar bone loss. This suggests pregnancy induced downregulating of Treg cells plays a pivotal role in the onset of gingival inflammation and subsequent periodontal tissue damage (Figure 10). 


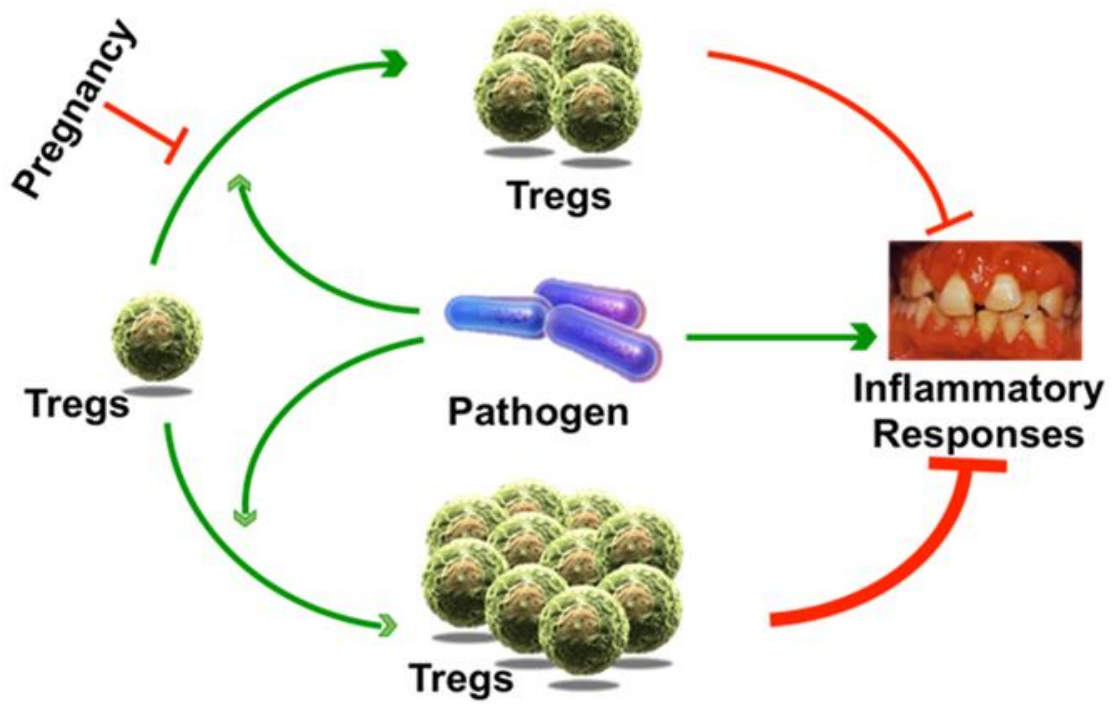

Figure 10. Schematic depiction of immunological mechanism of pregnancy inhibition on Treg response to oral pathogens.

The discovery of a new CD4+ T cell subset, Th17 cells, has provided greater insight into the pathogenesis of periodontal disease. Th17 cells are known inflammatory regulators and their production of IL-17 has been associated with inducing periodontal tissue inflammation and bone resorption (W.-C. Cheng et al., 2014; Eskan et al., 2012). In our analysis of pro-inflammatory cytokine expression, we found a significant increase of IL-17 expression in the gingival tissue of pregnant mice (Fig. 4A). Additionally, greater number of Th17 cells was 
also observed in the draining lymph nodes (Fig. 8). The increase in Th17 cells and II-17 expression may be attributed to downregulation of Treg development during pregnancy; in particular, Treg cell production of IL-10 (Figure 6A). IL-10 is an anti-inflammatory immunoregulatory cytokine produced by both Treg and Th2 cells and it has been implicated in playing a critical role in inhibiting inflammatory bone loss (Claudino et al., 2010). Recently, IL-10 has also been known to contribute to regulating Th17 cytokines in periodontal disease. IL-10 regulation of IL-17 was associated with reduced periodontal tissue inflammation and bone resorption (Moretti et al., 2015). Observed increase of IL-17 expression in gingival tissue during pregnancy may be attributed to downregulation of IL-10 expression. However, based on our study it is unclear if reduction of IL-10 expression is a result of decreased Treg number, which we observed, or Treg function, or both. Further studies will be needed to determine if Treg function is also affected during pregnancy.

The role of IL-17 in relation to bone loss has been described as both protective in some circumstances and detrimental in others. To maintain homeostasis, osteoblast bone formation must be in balance with osteoclast bone resorption. In inflammatory conditions such as rheumatoid arthritis and periodontal disease, this balance is shifted towards bone resorption thus causing osteolytic lesions (Lee, 2013). However, II-17 may serve a protective role in other inflammatory diseases like in post-menopausal osteoporosis. Goswami, et al. (2009) reported that bone loss due to ovariectomy-induced estrogen deficiency was more pronounced in mice lacking an IL-17 receptor than in controls, which 
was associated with increased production of leptin that is downregulated by II17A (Goswami, Hernández-Santos, Zuniga, \& Gaffen, 2009). Understanding the role of IL-17 in periodontal disease has proved to be challenging. Yu et al. (2007) reported that IL-17 receptor deficient mice exhibited more severe alveolar bone loss upon challenge by $P$. gingivalis, suggesting a bone-protective role for IL-17 signaling through the recruitment of neutrophils (Yu et al., 2007). Similarly, Th17deficient and IL-17 receptor-deficient mice are susceptible to oral candidiasis, a fungal infection of the oral mucosa known as thrush (Conti et al., 2009). However, in cases of chronic periodontal disease, the presence of increased levels of IL-17 and IL-23 in human gingival crevicular fluid correlates with the severity of attachment loss and pocket depth (Johnson, Wood, \& Serio, 2004; Lester, Bain, Johnson, \& Serio, 2007). In relation to our study, increased IL-17 levels in the gingival tissue was associated with the greater presence of oral bacteria and alveolar bone loss during pregnancy, suggesting detrimental bonedestructive role for II-17 and possible IL-17 neutrophil chemotaxis inhibition.

It is becoming increasingly evident that $\mathrm{TH} 17 /$ Treg balance is essential in meditating inflammatory diseases. Disruptions in the Th17/Treg homeostasis have been associated with rheumatoid arthritis, inflammatory bowel disease, and acute coronary syndrome (X. Cheng et al., 2008; Eastaff-Leung, Mabarrack, Barbour, Cummins, \& Barry, 2010; Niu, Cai, Huang, Shi, \& Wang, 2012). In periodontal disease, there is accumulating evidence that Th17/Treg paradigm is a critical player in the pathogenesis of the disease (George Hajishengallis, 2014). Despite marked presence of Treg cells in periodontal lesions, a recent study 
indicates $P$. gingivalis induces a shift of Th17/Treg balance towards Th17 proliferation thus progressing disease severity. Allam et al. (2011) reported the presence of CD68+ Mo-like cells as well as increased infiltration of IL-17 in the bottom region of chronic periodontitis lesions. Additionally, in vitro study revealed P. gingivalis ability to activate CD68+ Mo-like cell production of IL-23p19 which is attributed to inducing Th17 proliferation and subsequently II-17 expression (Allam et al., 2011). Further understanding of Th17/Treg paradigm in relation to periodontal disease could provide greater insight in the mechanisms behind pregnancy induced periodontal disease.

In summary, we found lower levels of Treg cells and molecule expression concomitant with increased numbers of Th17 cells in infection-induced pregnant mice compared to non-pregnant counterparts. The pregnant mice also exhibited exacerbated gingival inflammation and greater alveolar bone loss. Furthermore, the down-regulation of Treg cells does not lead to decreased oral bacterial number, consistent with our hypothesis that ligation and $P g$ infection-induced down-regulation of Treg cells plays a pivotal role in the more severe periodontal disease during pregnancy. 


\section{REFERENCES}

Adibrad, M., Deyhimi, P., Ganjalikhani Hakemi, M., Behfarnia, P., Shahabuei, M., \& Rafiee, L. (2012). Signs of the presence of Th17 cells in chronic periodontal disease. Journal of Periodontal Research, 47(4), 525-531. doi:10.1111/j.1600-0765.2011.01464.x

Adriaens, L. M., Alessandri, R., Spörri, S., Lang, N. P., \& Persson, G. R. (2008). Does Pregnancy Have an Impact on the Subgingival Microbiota? J Periodontol, 80(1), 72-81. doi:10.1902/jop.2009.080012

Alberts B, J. A., Lewis J, et al. . (2002)Molecular Biology of the Cell (4th Edition ed.). New York: Garland Science. Retrieved from https://www.ncbi.nlm.nih.gov/books/NBK26827/.

Allam, J.-P., Duan, Y., Heinemann, F., Winter, J., Götz, W., Deschner, J., . . Novak, N. (2011). IL23-producing CD68+ macrophage-like cells predominate within an IL-17-polarized infiltrate in chronic periodontitis lesions. Journal of Clinical Periodontology, 38(10), 879886. doi:10.1111/j.1600-051X.2011.01752.x

Aoyagi, T., Sugawara-Aoyagi, M., Yamazaki, K., \& Hara, K. (1995). Interleukin 4 (IL-4) and IL-6producing memory $\mathrm{T}$-cells in peripheral blood and gingival tissues in periodontitis patients with high serum antibody titers to Porphyromonas gingivalis. Oral Microbiology and Immunology, 10(5), 304-310. doi:10.1111/j.1399-302X.1995.tb00159.x

Arafat, A. H. (1974). Periodontal Status During Pregnancy. J Periodontol, 45(8.2), 641-643. doi:10.1902/jop.1974.45.8.2.641

Armitage, G. C. (1995). Clinical evaluation of periodontal diseases. Periodontol 2000, 7(1), 39-53. doi:10.1111/j.1600-0757.1995.tb00035.x

Assuma, R., Oates, T., Cochran, D., Amar, S., \& Graves, D. T. (1998). IL-1 and TNF antagonists inhibit the inflammatory response and bone loss in experimental periodontitis. Journal of immunology, 160(1), 403-409.

Baker, P. J., Dixon, M., Evans, R. T., Dufour, L., Johnson, E., \& Roopenian, D. C. (1999). CD4(+) T Cells and the Proinflammatory Cytokines Gamma Interferon and Interleukin-6 Contribute to Alveolar Bone Loss in Mice. Infect Immun, 67(6), 2804-2809. 
Berezow, A. B., \& Darveau, R. P. (2011). Microbial Shift and Periodontitis. Periodontol 2000, 55(1), 36-47. doi:10.1111/j.1600-0757.2010.00350.x

Bettelli, E., Carrier, Y., Gao, W., Korn, T., Strom, T. B., Oukka, M., ... Kuchroo, V. K. (2006). Reciprocal developmental pathways for the generation of pathogenic effector TH17 and regulatory T cells. Nature, 441(7090), 235-238. doi:http://www.nature.com/nature/journal/v441/n7090/suppinfo/nature04753_S1.ht $\mathrm{ml}$

Borgo, P. V., Rodrigues, V. A. A., Feitosa, A. C. R., Xavier, K. C. B., \& Avila-Campos, M. J. (2014). Association between periodontal condition and subgingival microbiota in women during pregnancy: a longitudinal study. Journal of Applied Oral Science, 22(6), 528-533. doi:10.1590/1678-775720140164

Cardoso, C. R., Garlet, G. P., Moreira, A. P., Junior, W. M., Rossi, M. A., \& Silva, J. S. (2008). Characterization of $\mathrm{CD} 4+\mathrm{CD} 25+$ natural regulatory $T$ cells in the inflammatory infiltrate of human chronic periodontitis. J Leukoc Biol, 84(1), 311-318. doi:10.1189/jlb.0108014

Carrillo-de-Albornoz, A., Figuero, E., Herrera, D., \& Bascones-Martinez, A. (2010). Gingival changes during pregnancy: II. Influence of hormonal variations on the subgingival biofilm. Journal of clinical periodontology, 37(3), 230-240. doi:10.1111/j.1600051X.2009.01514.x

Carrillo-de-Albornoz, A., Figuero, E., Herrera, D., \& Bascones-Martínez, A. (2010). Gingival changes during pregnancy: II. Influence of hormonal variations on the subgingival biofilm. Journal of Clinical Periodontology, 37(3), 230-240. doi:10.1111/j.1600051X.2009.01514.x

Cekici, A., Kantarci, A., Hasturk, H., \& Van Dyke, T. E. (2014). Inflammatory and immune pathways in the pathogenesis of periodontal disease. Periodontol 2000, 64(1), 57-80. doi:10.1111/prd.12002

Chambrone, L., Guglielmetti, M. R., Pannuti, C. M., \& Chambrone, L. A. (2011). Evidence grade associating periodontitis to preterm birth and/or low birth weight: I. A systematic review of prospective cohort studies. Journal of Clinical Periodontology, 38(9), 795-808. doi:10.1111/j.1600-051X.2011.01755.x

Chen, T., Yu, W.-H., Izard, J., Baranova, O. V., Lakshmanan, A., \& Dewhirst, F. E. (2010). The Human Oral Microbiome Database: a web accessible resource for investigating oral 
microbe taxonomic and genomic information. Database: The Journal of Biological Databases and Curation, 2010, baq013. doi:10.1093/database/baq013

Chen, W., Jin, W., Hardegen, N., Lei, K.-j., Li, L., Marinos, N., ... Wahl, S. M. (2003). Conversion of Peripheral CD4(+)CD25(-) Naive T Cells to CD4(+)CD25(+) Regulatory T Cells by TGF- $\beta$ Induction of Transcription Factor Foxp3. J Exp Med, 198(12), 1875-1886. doi:10.1084/jem.20030152

Cheng, W.-C., Hughes, F. J., \& Taams, L. S. (2014). The presence, function and regulation of IL-17 and Th17 cells in periodontitis. Journal of Clinical Periodontology, 41(6), 541-549. doi:10.1111/jcpe.12238

Cheng, X., Yu, X., Ding, Y.-j., Fu, Q.-q., Xie, J.-j., Tang, T.-t., . . Liao, Y.-h. (2008). The Th17/Treg imbalance in patients with acute coronary syndrome. Clinical Immunology, 127(1), 8997. doi:http://doi.org/10.1016/j.clim.2008.01.009

Christensen, K., Gaist, D., Jeune, B., \& Vaupel, J. W. (1998). A tooth per child? Lancet, 352(9123), 204. doi:10.1016/S0140-6736(05)77810-7

Claudino, M., Garlet, T. P., Cardoso, C. R. B., De Assis, G. F., Taga, R., Cunha, F. Q., . . Garlet, G. P. (2010). Down-regulation of expression of osteoblast and osteocyte markers in periodontal tissues associated with the spontaneous alveolar bone loss of interleukin-10 knockout mice. European Journal of Oral Sciences, 118(1), 19-28. doi:10.1111/j.16000722.2009.00706.x

Cohen, D. W., Shapiro, J., Friedman, L., Kyle, G. C., \& Franklin, S. (1971). A longitudinal investigation of the periodontal changes during pregnancy and fifteen months postpartum. II. Journal of periodontology, 42(10), 653-657. doi:10.1902/jop.1971.42.10.653

Conti, H. R., Shen, F., Nayyar, N., Stocum, E., Sun, J. N., Lindemann, M. J., . . Gaffen, S. L. (2009). Th17 cells and IL-17 receptor signaling are essential for mucosal host defense against oral candidiasis. J Exp Med, 206(2), 299-311. doi:10.1084/jem.20081463

Darveau, R. P. (2010). Periodontitis: a polymicrobial disruption of host homeostasis. Nat Rev Micro, 8(7), 481-490. doi:10.1038/nrmicro2337

Darveau, R. P., Hajishengallis, G., \& Curtis, M. A. (2012). Porphyromonas gingivalis as a potential community activist for disease. J Dent Res, 91(9), 816-820.

doi:10.1177/0022034512453589 
Dewhirst, F. E., Chen, T., Izard, J., Paster, B. J., Tanner, A. C., Yu, W. H., . . Wade, W. G. (2010). The human oral microbiome. J Bacteriol, 192(19), 5002-5017. doi:10.1128/jb.00542-10

Eastaff-Leung, N., Mabarrack, N., Barbour, A., Cummins, A., \& Barry, S. (2010). Foxp3+ Regulatory T Cells, Th17 Effector Cells, and Cytokine Environment in Inflammatory Bowel Disease. Journal of Clinical Immunology, 30(1), 80-89. doi:10.1007/s10875-0099345-1

Emmatty, R., Mathew, J. J., \& Kuruvilla, J. (2013). Comparative evaluation of subgingival plaque microflora in pregnant and non-pregnant women: A clinical and microbiologic study. Journal of Indian Society of Periodontology, 17(1), 47-51. doi:10.4103/0972124X.107474

Eskan, M. A., Jotwani, R., Abe, T., Chmelar, J., Lim, J. H., Liang, S., . . Hajishengallis, G. (2012). The leukocyte integrin antagonist Del-1 inhibits IL-17-mediated inflammatory bone loss. Nature immunology, 13(5), 465-473. doi:10.1038/ni.2260

Garlet, G. P. (2010). Destructive and Protective Roles of Cytokines in Periodontitis: A Reappraisal from Host Defense and Tissue Destruction Viewpoints. J Dent Res, 89(12), 1349-1363. doi:10.1177/0022034510376402

Garlet, G. P., Cardoso, C. R., Mariano, F. S., Claudino, M., De Assis, G. F., Campanelli, A. P., . . Silva, J. S. (2010). Regulatory T cells attenuate experimental periodontitis progression in mice. Journal of Clinical Periodontology, 37(7), 591-600. doi:10.1111/j.1600051X.2010.01586.x

Geisinger, M. L., Geurs, N. C., Bain, J. L., Kaur, M., Vassilopoulos, P. J., Cliver, S. P., . . Reddy, M. S. (2014). Oral health education and therapy reduces gingivitis during pregnancy. Journal of Clinical Periodontology, 41(2), 141-148. doi:10.1111/jcpe.12188

Gorelik, L., Constant, S., \& Flavell, R. A. (2002). Mechanism of Transforming Growth Factor $\beta-$ induced Inhibition of T Helper Type 1 Differentiation. J Exp Med, 195(11), 1499-1505. doi:10.1084/jem.20012076

Goswami, J., Hernández-Santos, N., Zuniga, L. A., \& Gaffen, S. L. (2009). A Bone-Protective Role for IL-17 Receptor Signaling in Ovariectomy-Induced Bone Loss. European journal of immunology, 39(10), 2831-2839. doi:10.1002/eji.200939670

Guo, F., Iclozan, C., Suh, W.-K., Anasetti, C., \& Yu, X.-Z. (2008). CD28 Controls Differentiation of Regulatory T Cells from Naive CD4 T Cells. J Immunol, 181(4), 2285-2291. 
Gursoy, M., Pajukanta, R., Sorsa, T., \& Kononen, E. (2008). Clinical changes in periodontium during pregnancy and post-partum. Journal of clinical periodontology, 35(7), 576-583. doi:10.1111/j.1600-051X.2008.01236.x

Gürsoy, M., Pajukanta, R., Sorsa, T., \& Könönen, E. (2008). Clinical changes in periodontium during pregnancy and post-partum. Journal of Clinical Periodontology, 35(7), 576-583. doi:10.1111/j.1600-051X.2008.01236.x

Hajishengallis, G. (2014). Immuno-microbial pathogenesis of periodontitis: Keystones, pathobionts, and the host response. Trends in immunology, 35(1), 3-11. doi:10.1016/j.it.2013.09.001

Hajishengallis, G., Darveau, R. P., \& Curtis, M. A. (2012). The keystone-pathogen hypothesis. Nat Rev Microbiol, 10(10), 717-725. doi:10.1038/nrmicro2873

Hajishengallis, G., Krauss, J. L., Liang, S., McIntosh, M. L., \& Lambris, J. D. (2012). Pathogenic microbes and community service through manipulation of innate immunity. Advances in experimental medicine and biology, 946, 69-85. doi:10.1007/978-1-4614-0106-3_5

Hajishengallis, G., \& Lambris, J. D. (2012). Complement and dysbiosis in periodontal disease. Immunobiology, 217(11), 1111-1116. doi:10.1016/j.imbio.2012.07.007

Hajishengallis, G., Liang, S., Payne, M. A., Hashim, A., Jotwani, R., Eskan, M. A., . . Curtis, M. A. (2011). A Low-Abundance Biofilm Species Orchestrates Inflammatory Periodontal Disease through the Commensal Microbiota and the Complement Pathway. Cell host \& microbe, 10(5), 497-506. doi:10.1016/j.chom.2011.10.006

Holt, S. C., \& Ebersole, J. L. (2005). Porphyromonas gingivalis, Treponema denticola, and Tannerella forsythia: the "red complex", a prototype polybacterial pathogenic consortium in periodontitis. Periodontol 2000, 38, 72-122. doi:10.1111/j.16000757.2005.00113.x

Hori, S., Nomura, T., \& Sakaguchi, S. (2003). Control of Regulatory T Cell Development by the Transcription Factor <em>Foxp3</em>. Science, 299(5609), 1057-1061. doi:10.1126/science.1079490

Huber, S., Gagliani, N., Esplugues, E., O'Connor, W., Huber, F. J., Chaudhry, A., . . Flavell, R. A. (2011). Th17 cells express interleukin-10 receptor and are controlled by Foxp3(-) and Foxp3(+) regulatory CD4(+) T cells in an interleukin-10 dependent manner. Immunity, 34(4), 554-565. doi:10.1016/j.immuni.2011.01.020 
Ivanov, I. I., McKenzie, B. S., Zhou, L., Tadokoro, C. E., Lepelley, A., Lafaille, J. J., . . L Littman, D. R. The Orphan Nuclear Receptor ROR\&\#x3b3;t Directs the Differentiation Program of Proinflammatory IL-17<sup>+</sup> T Helper Cells. Cell, 126(6), 1121-1133. doi:10.1016/j.cell.2006.07.035

Jin, B., Sun, T., Yu, X.-H., Yang, Y.-X., \& Yeo, A. E. T. (2012). The Effects of TLR Activation on T-Cell Development and Differentiation. Clinical and Developmental Immunology, 2012, 836485. doi:10.1155/2012/836485

Johnson, R. B., Wood, N., \& Serio, F. G. (2004). Interleukin-11 and IL-17 and the Pathogenesis of Periodontal Disease. J Periodontol, 75(1), 37-43. doi:10.1902/jop.2004.75.1.37

Kaur, M., Geisinger, M. L., Geurs, N. C., Griffin, R., Vassilopoulos, P. J., Vermeulen, L., . . Reddy, M. S. (2014). Effect of Intensive Oral Hygiene Regimen During Pregnancy on Periodontal Health, Cytokine Levels, and Pregnancy Outcomes: A Pilot Study. J Periodontol, 85(12), 1684-1692. doi:10.1902/jop.2014.140248

Kobayashi, R., Kono, T., Bolerjack, B. A., Fukuyama, Y., Gilbert, R. S., Fujihashi, K., . . Fujihashi, K. (2011). Induction of IL-10-producing CD4(+) T-cells in Chronic Periodontitis. J Dent Res, 90(5), 653-658. doi:10.1177/0022034510397838

Kornman, K. S., \& Loesche, W. J. (1980). The subgingival microbial flora during pregnancy. Journal of periodontal research, 15(2), 111-122.

Lachat, M. F., Solnik, A. L., Nana, A. D., \& Citron, T. L. (2011). Periodontal disease in pregnancy: review of the evidence and prevention strategies. J Perinat Neonatal Nurs, 25(4), 312319. doi:10.1097/JPN.0b013e31821072e4

Laine, M. A. (2002a). Effect of pregnancy on periodontal and dental health. Acta Odontol Scand, $60(5), 257-264$.

Laine, M. A. (2002b). Effect of pregnancy on periodontal and dental health. Acta odontologica Scandinavica, 60(5), 257-264.

Lee, Y. (2013). The role of interleukin-17 in bone metabolism and inflammatory skeletal diseases. BMB Reports, 46(10), 479-483. doi:10.5483/BMBRep.2013.46.10.141

Lester, S. R., Bain, J. L., Johnson, R. B., \& Serio, F. G. (2007). Gingival Concentrations of Interleukin-23 and -17 at Healthy Sites and at Sites of Clinical Attachment Loss. J Periodontol, 78(8), 1545-1550. doi:10.1902/jop.2007.060458 
Li, M. O., Wan, Y. Y., \& Flavell, R. A. T Cell-Produced Transforming Growth Factor-\&\#x3b2;1 Controls T Cell Tolerance and Regulates Th1- and Th17-Cell Differentiation. Immunity, 26(5), 579-591. doi:10.1016/j.immuni.2007.03.014

Lieff, S., Boggess, K. A., Murtha, A. P., Jared, H., Madianos, P. N., Moss, K., . . Offenbacher, S. (2004). The oral conditions and pregnancy study: periodontal status of a cohort of pregnant women. Journal of periodontology, 75(1), 116-126. doi:10.1902/jop.2004.75.1.116

Macedo, J. F., Ribeiro, R. A., Machado, F. C., Assis, N. M. S. P., Alves, R. T., Oliveira, A. S., \& Ribeiro, L. C. (2014). Periodontal disease and oral health-related behavior as factors associated with preterm birth: a case-control study in south-eastern Brazil. Journal of Periodontal Research, 49(4), 458-464. doi:10.1111/jre.12124

Machuca, G., Khoshfeiz, O., Lacalle, J. R., Machuca, C., \& Bullon, P. (1999). The influence of general health and socio-cultural variables on the periodontal condition of pregnant women. Journal of periodontology, 70(7), 779-785. doi:10.1902/jop.1999.70.7.779

Maekawa, T., Krauss, J. L., Abe, T., Jotwani, R., Triantafilou, M., Triantafilou, K., . . . Hajishengallis, G. (2014). Porphyromonas gingivalis manipulates complement and TLR signaling to uncouple bacterial clearance from inflammation and promote dysbiosis. Cell host \& microbe, 15(6), 768-778. doi:10.1016/j.chom.2014.05.012

Masada, M. P., Persson, R., Kenney, J. S., Lee, S. W., Page, R. C., \& Allison, A. C. (1990). Measurement of interleukin-1 alpha and -1 beta in gingival crevicular fluid: implications for the pathogenesis of periodontal disease. Journal of periodontal research, 25(3), 156163.

Mira, A., Simon-Soro, A., \& Curtis, M. A. (2017). Role of microbial communities in the pathogenesis of periodontal diseases and caries. J Clin Periodontol, 44 Suppl 18, S23-s38. doi:10.1111/jcpe.12671

Mjosberg, J., Svensson, J., Johansson, E., Hellstrom, L., Casas, R., Jenmalm, M. C., . . Ernerudh, J. (2009). Systemic reduction of functionally suppressive CD4dimCD25highFoxp3+ Tregs in human second trimester pregnancy is induced by progesterone and 17beta-estradiol. $J$ Immunol, 183(1), 759-769. doi:10.4049/jimmunol.0803654

Moretti, S., Bartolommei, L., Galosi, C., Renga, G., Oikonomou, V., Zamparini, F., . . Romani, L. (2015). Fine-tuning of Th17 Cytokines in Periodontal Disease by IL-10. J Dent Res, 94(9), 1267-1275. doi:10.1177/0022034515591790 
Moss, K. L., Beck, J. D., \& Offenbacher, S. (2005). Clinical risk factors associated with incidence and progression of periodontal conditions in pregnant women. Journal of clinical periodontology, 32(5), 492-498. doi:10.1111/j.1600-051X.2005.00703.x

Nakajima, T., Ueki-Maruyama, K., Oda, T., Ohsawa, Y., Ito, H., Seymour, G. J., \& Yamazaki, K. (2005). Regulatory T-cells Infiltrate Periodontal Disease Tissues. J Dent Res, 84(7), 639643. doi:10.1177/154405910508400711

Niu, Q., Cai, B., Huang, Z.-C., Shi, Y.-y., \& Wang, L.-I. (2012). Disturbed Th17/Treg balance in patients with rheumatoid arthritis. Rheumatology International, 32(9), 2731-2736. doi:10.1007/s00296-011-1984-x

Pazos, M., Sperling, R. S., Moran, T. M., \& Kraus, T. A. (2012). The influence of pregnancy on systemic immunity. Immunologic Research, 54(1), 254-261. doi:10.1007/s12026-0128303-9

Perunovic, N. D., Rakic, M. M., Nikolic, L. I., Jankovic, S. M., Aleksic, Z. M., Plecas, D. V., . . Cakic, S. S. (2015). The Association Between Periodontal Inflammation and Labor Triggers (Elevated Cytokine Levels) in Preterm Birth: A Cross-Sectional Study. J Periodontol, 87(3), 248-256. doi:10.1902/jop.2015.150364

Pihlstrom, B. L., Michalowicz, B. S., \& Johnson, N. W. Periodontal diseases. The Lancet, 366(9499), 1809-1820. doi:http://dx.doi.org/10.1016/S0140-6736(05)67728-8

Raber-Durlacher, J. E., Leene, W., Palmer-Bouva, C. C., Raber, J., \& Abraham-Inpijn, L. (1993). Experimental gingivitis during pregnancy and post-partum: immunohistochemical aspects. J Periodontol, 64(3), 211-218. doi:10.1902/jop.1993.64.3.211

Raber-Durlacher, J. E., van Steenbergen, T. J., Van der Velden, U., de Graaff, J., \& AbrahamInpijn, L. (1994). Experimental gingivitis during pregnancy and post-partum: clinical, endocrinological, and microbiological aspects. Journal of clinical periodontology, 21(8), 549-558.

Raphael, I., Nalawade, S., Eagar, T. N., \& Forsthuber, T. G. (2015). T cell subsets and their signature cytokines in autoimmune and inflammatory diseases. Cytokine, 74(1), 5-17. doi:10.1016/j.cyto.2014.09.011

Read, S., Greenwald, R., Izcue, A., Robinson, N., Mandelbrot, D., Francisco, L., . . Powrie, F. (2006). Blockade of CTLA-4 on CD4<sup $>+</$ sup $>$ CD $25<$ sup $>+</$ sup $>$ Regulatory T Cells Abrogates Their Function In Vivo. The Journal of Immunology, 177(7), 4376-4383. doi:10.4049/jimmunol.177.7.4376 
Repeke, C. E., Ferreira Jr, S. B., Claudino, M., Silveira, E. M., de Assis, G. F., Avila-Campos, M. J., . . . Garlet, G. P. (2010). Evidences of the cooperative role of the chemokines CCL3, CCL4 and CCL5 and its receptors CCR1+ and CCR5+ in RANKL+ cell migration throughout experimental periodontitis in mice. Bone, 46(4), 1122-1130. doi:http://dx.doi.org/10.1016/j.bone.2009.12.030

Richert-Spuhler, L. E., \& Lund, J. M. (2015). The Immune Fulcrum: Regulatory T Cells Tip the Balance Between Pro- and Anti-inflammatory Outcomes upon Infection. Progress in molecular biology and translational science, 136, 217-243. doi:10.1016/bs.pmbts.2015.07.015

Rossomando, E. F., Kennedy, J. E., \& Hadjimichael, J. (1990). Tumour necrosis factor alpha in gingival crevicular fluid as a possible indicator of periodontal disease in humans. Archives of oral biology, 35(6), 431-434.

Sakaguchi, S., Miyara, M., Costantino, C. M., \& Hafler, D. A. (2010). FOXP3+ regulatory T cells in the human immune system. Nat Rev Immunol, 10(7), 490-500.

Siqueira, J. F., Jr., \& Rocas, I. N. (2009). Community as the unit of pathogenicity: an emerging concept as to the microbial pathogenesis of apical periodontitis. Oral Surg Oral Med Oral Pathol Oral Radiol Endod, 107(6), 870-878. doi:10.1016/j.tripleo.2009.01.044

Smigiel, K. S., Srivastava, S., Stolley, J. M., \& Campbell, D. J. (2014). Regulatory T cell homeostasis: steady-state maintenance and modulation during inflammation. Immunological reviews, 259(1), 40-59. doi:10.1111/imr.12170

Taani, D. Q., Habashneh, R., Hammad, M. M., \& Batieha, A. (2003). The periodontal status of pregnant women and its relationship with socio-demographic and clinical variables. Journal of oral rehabilitation, 30(4), 440-445.

Takahama, Y. (2006). Journey through the thymus: stromal guides for T-cell development and selection. Nat Rev Immunol, 6(2), 127-135.

Tilakaratne, A., Soory, M., Ranasinghe, A. W., Corea, S. M., Ekanayake, S. L., \& de Silva, M. (2000a). Periodontal disease status during pregnancy and 3 months post-partum, in a rural population of Sri-Lankan women. Journal of clinical periodontology, 27(10), 787792.

Tilakaratne, A., Soory, M., Ranasinghe, A. W., Corea, S. M. X., Ekanayake, S. L., \& De Silva, M. (2000b). Periodontal disease status during pregnancy and 3 months post-partum, in a 
rural population of Sri-Lankan women. Journal of Clinical Periodontology, 27(10), 787792. doi:10.1034/j.1600-051x.2000.027010787.x

Wang, M., Krauss, J. L., Domon, H., Hosur, K. B., Liang, S., Magotti, P., . . Hajishengallis, G. (2010). Microbial Hijacking of Complement-Toll-like Receptor Crosstalk. Science signaling, 3(109), ra11-ra11. doi:10.1126/scisignal.2000697

Weaver, C. T., Hatton, R. D., Mangan, P. R., \& Harrington, L. E. (2007). IL-17 Family Cytokines and the Expanding Diversity of Effector T Cell Lineages. Annual review of immunology, 25(1), 821-852. doi:doi:10.1146/annurev.immunol.25.022106.141557

Wu, M., Chen, S.-W., \& Jiang, S.-Y. (2015). Relationship between Gingival Inflammation and Pregnancy. Mediators of Inflammation, 2015, 623427. doi:10.1155/2015/623427

Yang, X. O., Pappu, B. P., Nurieva, R., Akimzhanov, A., Kang, H. S., Chung, Y., .. . Dong, C. T Helper 17 Lineage Differentiation Is Programmed by Orphan Nuclear Receptors ROR\&\#x3b1; and ROR\&\#x3b3. Immunity, 28(1), 29-39. doi:10.1016/j.immuni.2007.11.016

Yu, J. J., Ruddy, M. J., Wong, G. C., Sfintescu, C., Baker, P. J., Smith, J. B., . . Gaffen, S. L. (2007). An essential role for IL-17 in preventing pathogen-initiated bone destruction: recruitment of neutrophils to inflamed bone requires IL-17 receptor-dependent signals. Blood, 109(9), 3794-3802. doi:10.1182/blood-2005-09-010116

Zheng, Y., Manzotti, C. N., Liu, M., Burke, F., Mead, K. I., \& Sansom, D. M. (2004). CD86 and CD80 Differentially Modulate the Suppressive Function of Human Regulatory T Cells. The Journal of Immunology, 172(5), 2778-2784. doi:10.4049/jimmunol.172.5.2778

Zhou, L., Ivanov, I. I., Spolski, R., Min, R., Shenderov, K., Egawa, T., . . Littman, D. R. (2007). IL-6 programs TH-17 cell differentiation by promoting sequential engagement of the IL-21 and IL-23 pathways. Nat Immunol, 8(9), 967-974. doi:http://www.nature.com/ni/journal/v8/n9/suppinfo/ni1488_S1.html

Zhou, L., Lopes, J. E., Chong, M. M. W., Ivanov, I. I., Min, R., Victora, G. D., . . Littman, D. R. (2008). TGF-[bgr]-induced Foxp3 inhibits TH17 cell differentiation by antagonizing ROR[ggr]t function. Nature, 453(7192), 236-240. doi:http://www.nature.com/nature/journal/v453/n7192/suppinfo/nature06878_S1.ht $\mathrm{ml}$ 
Zhu, J., Yamane, H., \& Paul, W. E. (2010). Differentiation of Effector CD4 T Cell Populations. Annual review of immunology, 28, 445-489. doi:10.1146/annurev-immunol-030409101212 
CURRICULUM VITA

Aislinn Hays

509-393-5464

aislinn.hays@gmail.com

\section{RESEARCH EXPERIENCE AND TRAINING}

\section{Graduate Student}

\section{August 2015 - Present}

\section{M.S. Oral Biology, University of Louisville School of Dentistry, Department} of Oral Immunology and Infectious Diseases, Louisville, KY

Investigating the etiology of pregnancy gingivitis. More specifically, examining the role of regulatory $T$ cells in oral infection and inflammation during pregnancy. In addition, testing the ability of Nemo Binding Domain perfluorocarbon nanoparticles to inhibit gingival tissue inflammation and alveolar bone loss in an animal periodontitis model. 


\section{Laboratory Technician}

January 2015 -August 2015

\section{Albert Einstein College of Medicine, Department of Pathology, Bronx, New York}

Set up new laboratory and mouse colony to continue previous research on understanding skeletal and cardiac muscle wasting and regeneration in Muscular Dystrophy and aging. This research examines the molecular mechanisms that contribute to the production of fibrosis and muscle wasting as well as the development of pharmacotherapies targeting these mechanisms. Responsibilities include managing the lab, general lab maintenance, ordering supplies, mouse husbandry, tissue dissection and preservation, genotyping, and Q-RT-PCR.

\section{March 2012 - December 2014}

\section{University of Washington, Department of Pathology, Seattle, WA.}

Conducted experiments to understand skeletal and cardiac muscle wasting and regeneration in relation to disease (Muscular Dystrophy) and aging.

Responsibilities included general lab maintenance, mouse husbandry, tissue dissection and preservation, genotyping, tissue culture, Q-RT PCR and other cellular and molecular biology techniques. In addition I have trained many other personnel in these techniques. 


\section{Undergraduate Research Assistant}

June 2009 - March 2012.

University of Washington, Department of Pathology, Seattle, WA.

Contributed to research on skeletal and cardiac muscle in relation to muscular dystrophy. Conducted experiments primarily by using methods such as immunohistochemistry, immunofluorescence and histology. Also gained experience in mouse husbandry and tissue culture.

\section{EDUCATION}

\section{M.S. Oral Biology. 2015-Present}

University of Louisville, School of Dentistry, Louisville, KY

B.S. Cellular, Molecular, and Developmental Biology. 2007-2011.

University of Washington, Department of Biology. Seattle, WA.

High School Diploma and College in the High School Program. 2003-2007.

Wenatchee High School and Wenatchee Valley Community College, Wenatchee WA. 


\section{PUBLICATIONS}

1. Bone marrow cells do not engraft into skeletal muscle microvasculature but promote angiogenesis following acute injury. leronimakis N, Hays A, Reyes M. Experimental Hematology. 2012.

2. An in vitro culture system for long-term expansion of epithelial and mesenchymal salivary gland cells: role of TGF $\beta 1$ in salivary gland epithelial and mesenchymal differentiation. Janebodin $\mathrm{K}$, Buranaphatthana W, leronimakis N, Hays A, Reyes M. Biomed Research International. 2013.

3. Increased sphingosine 1-phosphate improves muscle regeneration in acutely injured mdx mice. leronimakis N, Pantoja M, Hays A, Dosey T, Qi J, Fischer K, Hoofnagle A, Sadilek M, Chamberlain J, Ruohola-Baker H, Reyes M. Skeletal Muscle. 2013.

4. Coronary adventitial cells are linked to perivascular cardiac fibrosis via TGF 1 signaling in the mdx mouse model of Duchenne Muscular Dystrophy. leronimakis N, Hays A, Janebodin K, Mahoney W, Duffield J, Majesky M, Reyes M. Journal of Molecular and Cellular Cardiology. 2013.

5. Molecular mechanism of sphingosine 1-phosphate action in Duchenne Muscular Dystrophy. Nguyen-Tran DH, Hait N, Sperber H, Qi J, Fischer K, leronimakis N, Pantoja M, Hays A, Allegood J, Reyes M, Spiegel S, RuoholaBaker H. Disease Models \& Mechanism. 2013.

6. Chlamydia Pneumoniae infection of lungs and macrophages indirectly stimulates the phenotypic conversion of smooth muscle cells and mesenchymal stem cells: potential roles in vascular calcification and fibrosis. Rosenfeld M, Cabbage S, leronimakis N, Preusch M, Lee, A, Ricks J, Janebodin K, Hays A, Wijelath E, Reyes M, Campbell, Lee A. Pathogens and Disease. 2014.

7. PDGFRa signaling promotes fibrosis in the skeletal muscles of Duchenne Muscular Dystrophy. Ieronimakis $\mathrm{N}_{2}$ Hays A, Janebodin K, Duffield J, Reyes M. Journal of Pathology. 2016. 


\section{POSTER AND *ORAL PRESENTATIONS}

- Research!Louisville 2016

- IMSD and STAR Research Symposium 2008-2009, 2011

- Undergraduate Research Symposium 2011

- UW HHMI Biology Undergraduate Research Symposium 2011

- Annual Biomedical Research Conference for Minority Students, 2011 St.

Louis, Mo

"Bone Marrow Derived Cells do Not Engraft into Skeletal Muscle

Microvasculature but Promote Angiogenesis Following Acute Injury" 